\title{
قراءة في أثر التمركز الثقافي في نشأة الهُوِّة الأوروبية
}

نصر الدين بن غنيسة

مقدمة:

إن السؤال: "لماذا تأخر المسلمون وتقدم غيرهم؟؟ يطرح ثنائية الأنا- الآخهـر في

صورة التضاد و المقابلة القائمة على الغلبة، ما يفضي بنا إلى أحد الموقفين: إمــــ (أنــا)

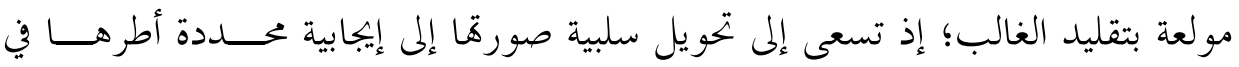
الثقافة الغالبة، وإما (أنا) مولعة باستلهام تاريخ غلبتها؛ لتصنع صورة ذاتيسـة تســمد إيجابيتها من قراءة سلبية لصورة الآخر الغالب. و كلا الموقفين يوحي بأن لا مقام لنا في الحداثة الغربية إلا من منطلق سلبيتنا المتجلية في رَدّيّ الفعل المتناقضــين (الإقـــدام أو الإحجام). إن هذا الطرح المؤسَّس على فكرة إقصائنا من الشراكة في الحداثة الغربية،

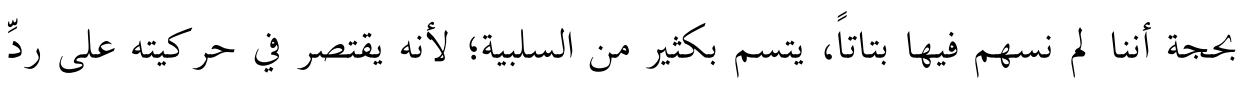
الفعل الحضاري. ولتجاوز هذه السلبية، فنحن مدعوون إلى الارتقاء فوق هذه الثنائية، وذلك باعتقادنا أن لنا الحقَّ في التعامل مع الحداثة، لا بوصفها ثقافة دخيلـــة غالبــة،

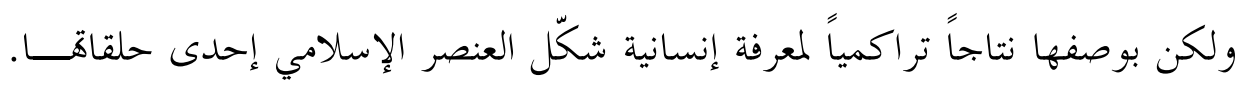
ومن بين السبل العلمية الكفيلة بتحقيق هذه القفزة الحضارية، مراجعة الركائز النظرية و المنهجية للخطاب التاريخي الغربي حين يتناول علاقته بالآخر الإسلامي. وهو ما ترنو

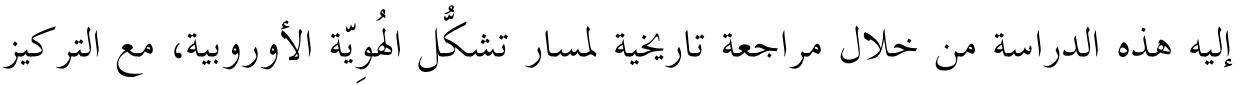
على مدى ترابط التزعة المركزية بأيديولوجيا الحداثة. 


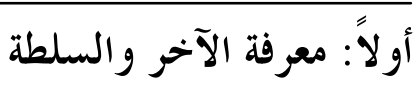

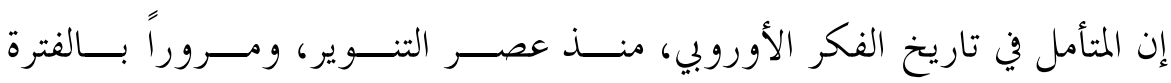
الاستعمارية، يدرك مدى ترابط نشأة الهوية الأوروبية بالحداثة، من حيث اســتخدام الأولى للثانية لبناء هوية لا فضل فيها للآخر الغريب في المساهمة في تشكيلها. وحتى يتم إقصاء هذا الآخر ذي الماضي الفاعل والحاضر السبي، كان لا بد من بحريده من صفة

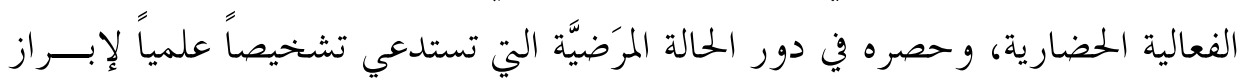
أعراض مرض التخلف؛ بغية إيجاد علاج "علموي" حداثي على النمط التنويري. فكان أن قضت الثقافة الغربية ردحاً من الزمن تبحث فيه عن عل سلطة معرفية تؤسس لعلاقتها بالآخر بوساطة العلم الدقيق، ما أفضى إلى نوع من التماهي بين الآخر، و الصورة التي

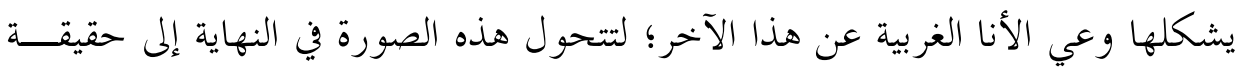
علمية، هي خلاصة خبرة المستشرق الشخصية، أو تحليلات عالم الـــفس، أو أنمـــاط بنيو ية أبدعها متخصص في علم الإنسان.

لقد بدأت هذه الرحلة العلموية نحو الآخر في عزّ عصر الموسوعات، حين طـرح

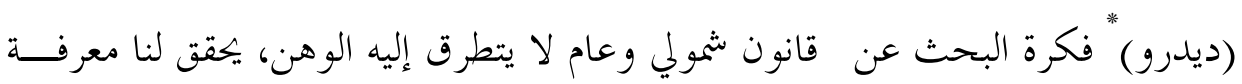

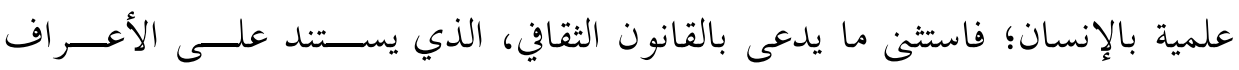

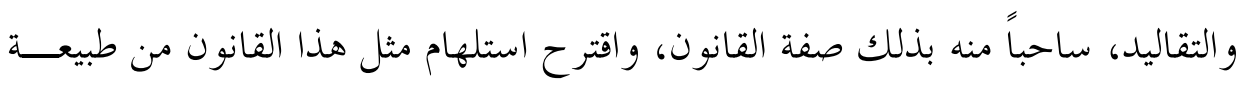

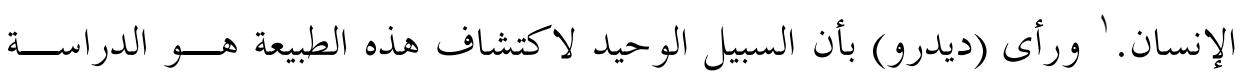
الدقيقة للوقائع، أو ما يمكن اختصاره في مفهوم المنهج. و تفصيلاً لهذا المنهج، يعلن (دو جيراندو) بو صفه وريثاً للعقلية الموسوعية، سأمه

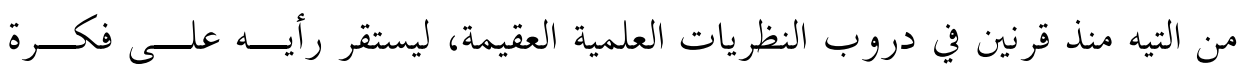
"فيلسوف فرنسي، يعد مؤسس الموسوعة الفرنسية، ومن مؤلفاته: الأفكار الفلسفية، وأفكار في تفسير الطبيعة.

${ }^{1}$ Todorov, Tzvetan. Nous et les autres, Paris: Points, 1989, p.37. تو Joseph-Marie De Gérando "

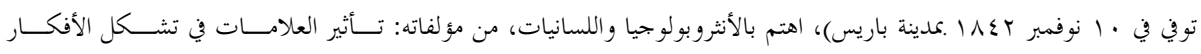


الملاحظة بوصفها بوابة للخروج من نفق التأمل إلى سعة التجربة المفضية إلى القانون.

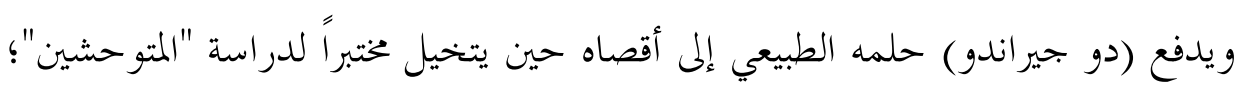

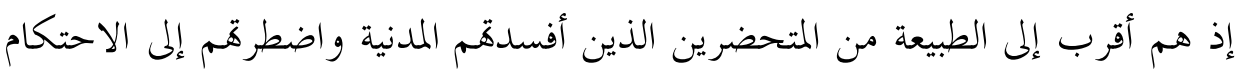

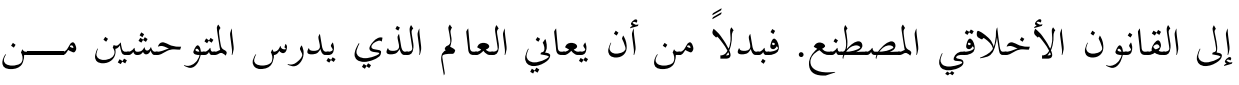

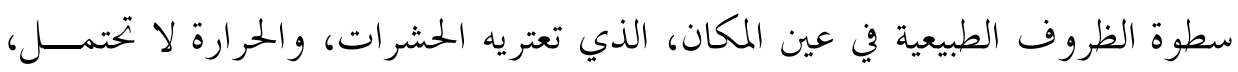
يقترح (دو جيراندو) أن يُنقل المتوحشون إلى باريس. وحتى تكون الملاحظة العلميـة فيسة

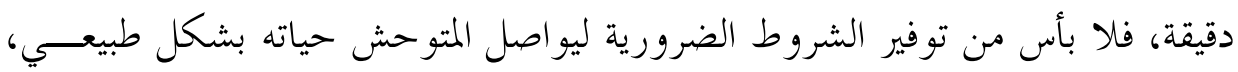

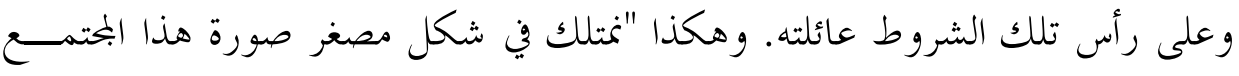

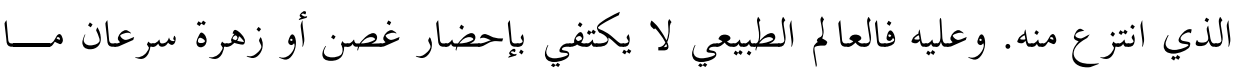

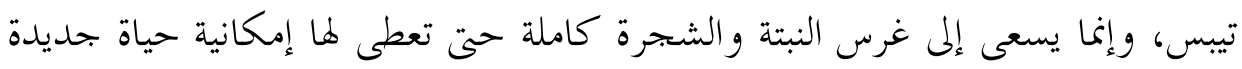

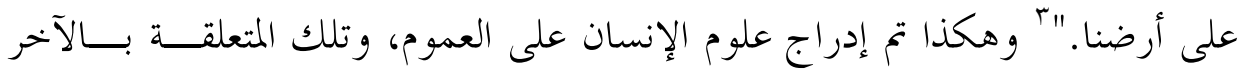
الغريب على الخصوص، ضمن العلوم الطبيعية، ما أدى إلى اختزال (الإنسان/ الآخسـر) إلى موضوع، والأنا إلى ذات، ولا علاقة بينهما سوى التضاد و المقابلة.

\section{ثانياً: حضور الآخر في صياغة الأنا}

ارتبطت هذذه التزعة العلمية فكرة التقابل والتضاد والمو اجهة لتتحول إلى "عمـــاد

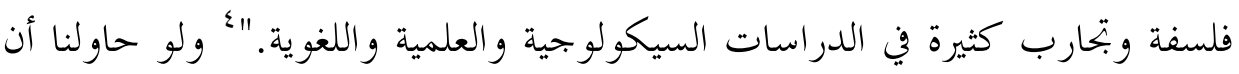

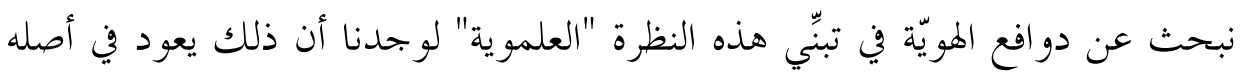

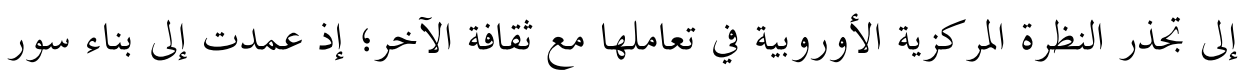
تاريخي يفصلها عن بقية الثقافات الأخرى، ويحدد خصوصيتها التي تقصي كل العناصر

${ }^{2}$ Todorov, Tzvetan. Nous et les autres, Paris: Points, 1989, p.41.

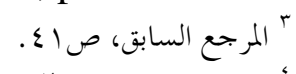
" ناصف، مصطفى. اللغة والتفسير والتواصل، الكويت: سلسلة عالم المعرفة، 990 (م) ص1/. 
الأجنبية التي ساهمت في بلورها؛ لتتحول الأنا إلى ذات، والآخر إلى موضوع خارجي قابل للدراسة و الفحص والملاحظة و التجربة.

ومن خحلال هذه الطروحات الشوفينية وأمثالها، "أعلن الغرب نفسه واحداً ووحيداً

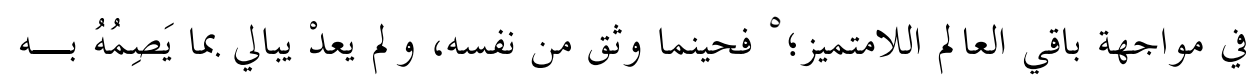

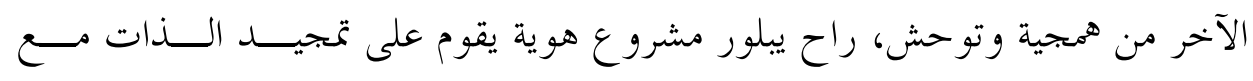

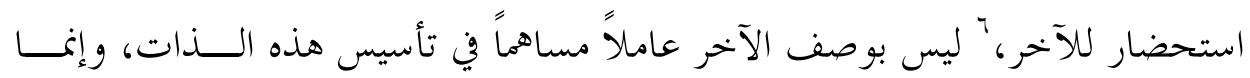

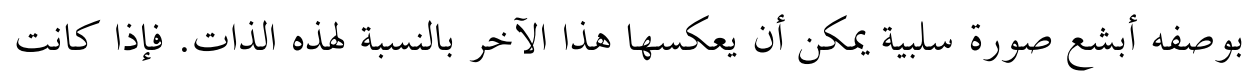

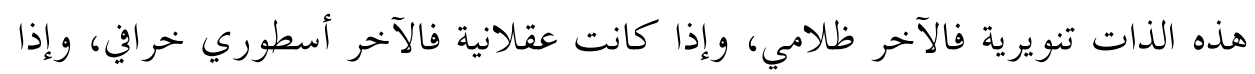

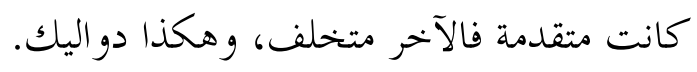

فالهوية الغربية، بعدما اكتمل بناؤها، راحت تضع لنفسها صورة تتماشى وموقعها

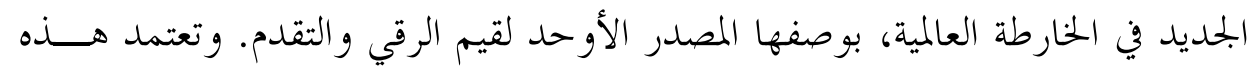

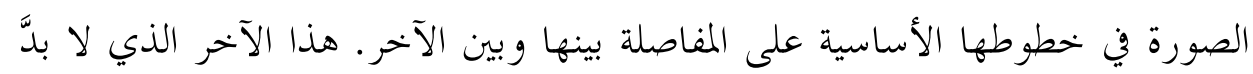

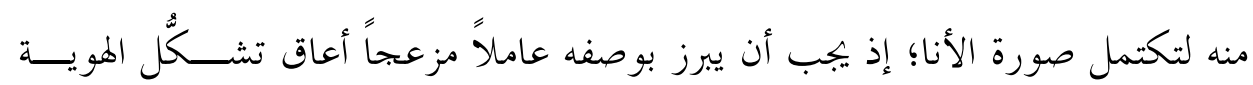

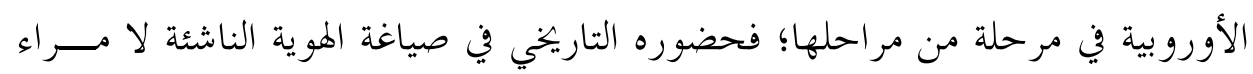
فيه، وإن اختلفت تقييمات هذا الحضور، فهو يُستدعى في الوعي الأوروبي عاملاً سلبياً

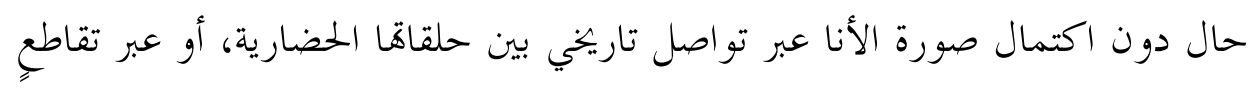

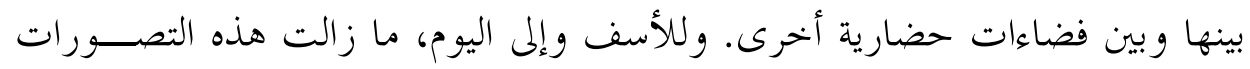

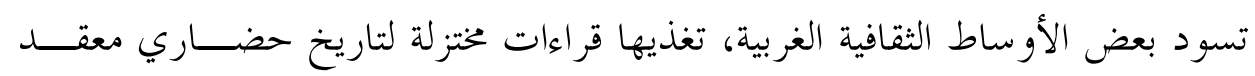
قامت هها أسماء علمية، سنتعرض لبعضها في هذه الدراسة، أكسبت شرعيتُها الأكاديميةُ

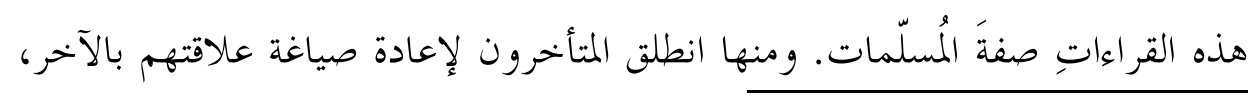
" الشوفينية Chauvinism الغلو في الوطنية أو القومية.

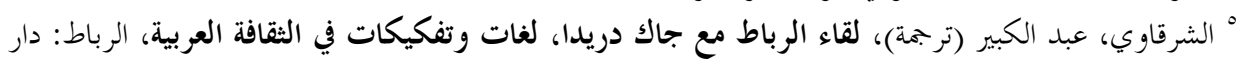

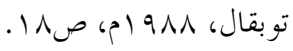

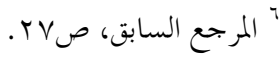




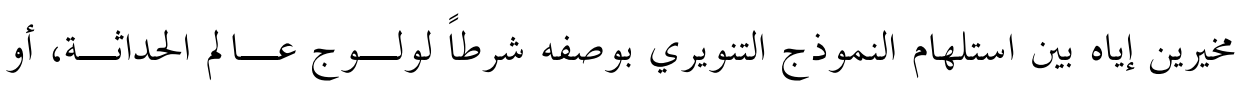

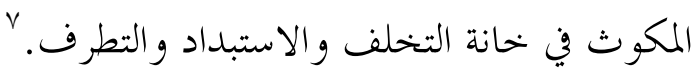

ولعل هذا الطرح قد أفضى إلى تشكُل هوية مشتتة بين الأنا والآخر، تلك الأنـــا

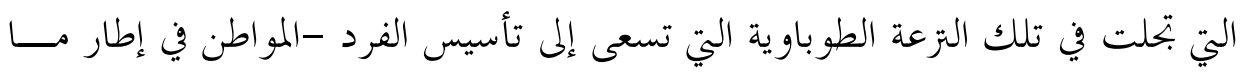

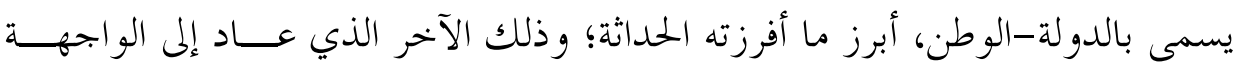

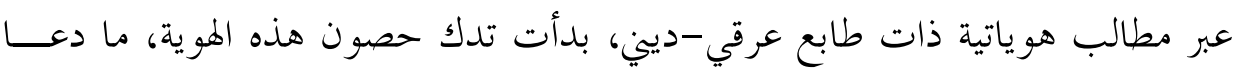

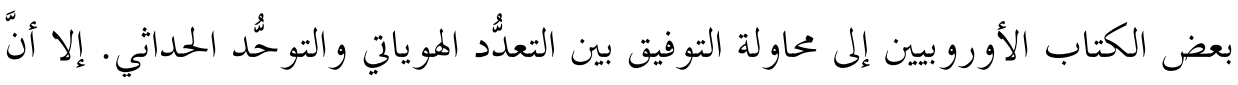

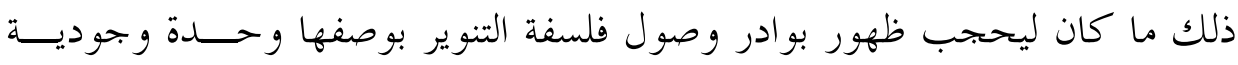

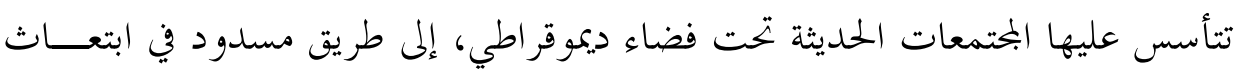

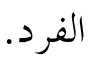

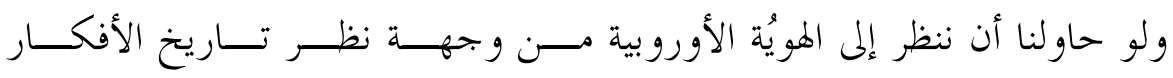

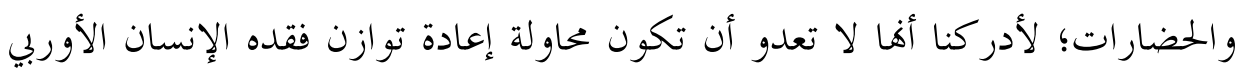

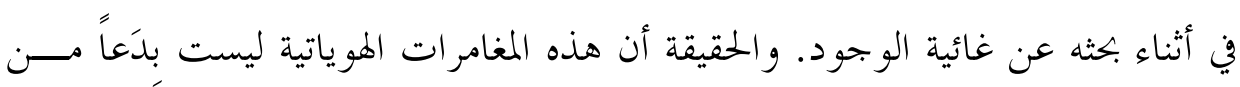

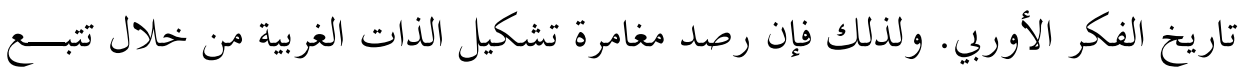

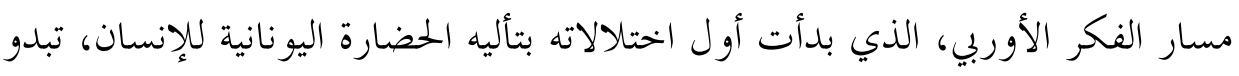
ضرورة منهجية تقتضيها النظرة الفاحصة (الميكروسكو بية) لمسار الأفكار. إنَّ عملية استقراء لخلفية الأزمة التي تعبر عنها الهوية الغربية تحيلـــــإلى حقيقتـــها

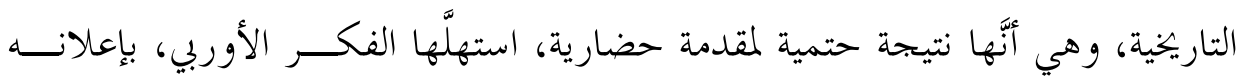

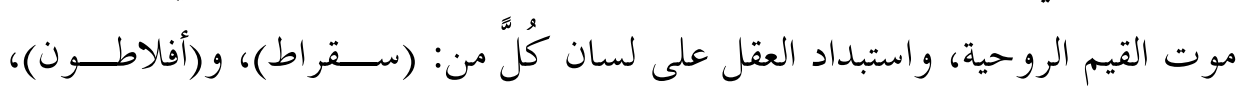

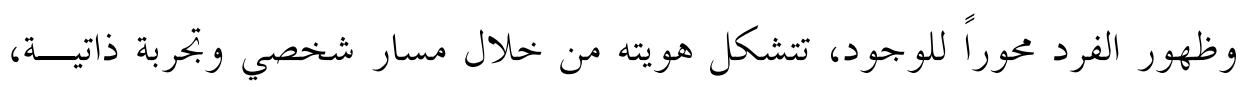

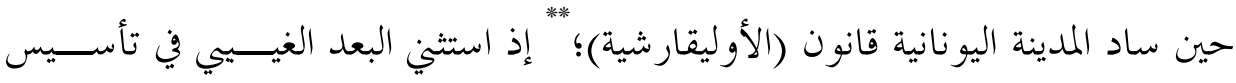

${ }^{7}$ Revue Courrier International, Hors série, Juin-Juillet 2003.

$$
\text { " وهو قانون يستني البعد الغيي في تأسيس العلاقات الإنسانية }
$$




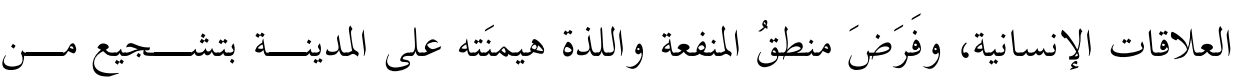

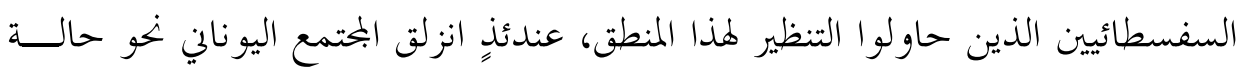

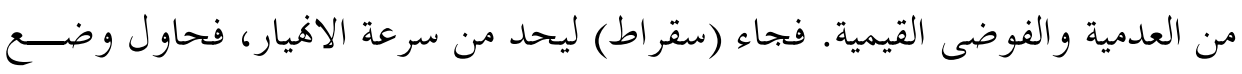

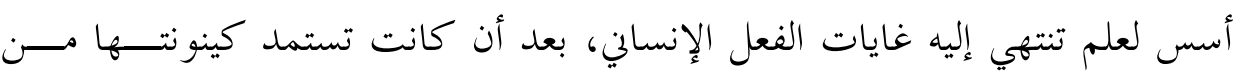

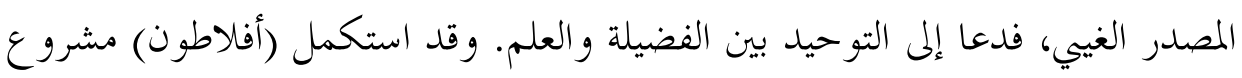

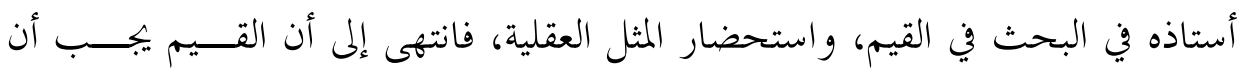

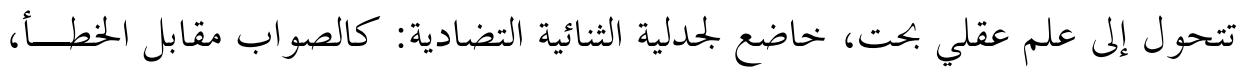

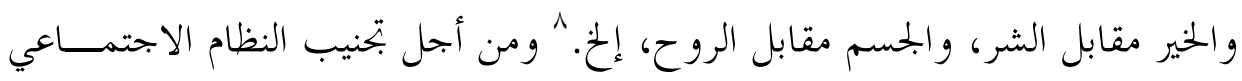

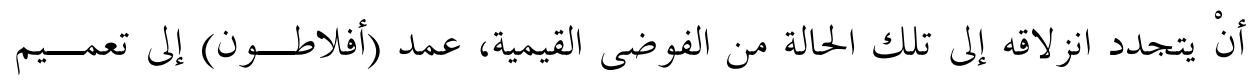

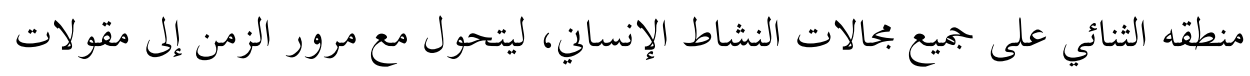

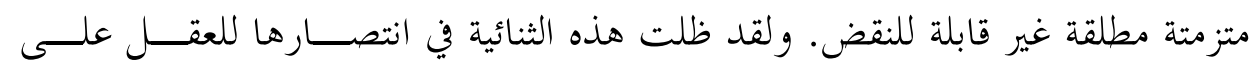
حساب الروح، وفي تمجيدها للبشري وتغيبها الإلهي، هي ديدن الخضـــارة اليونانيــة و الرومانية.

ولمًا وصلت هذه الحضارة في عهدها الروماني إلى هاية ذورقا، جاءت المســيحية

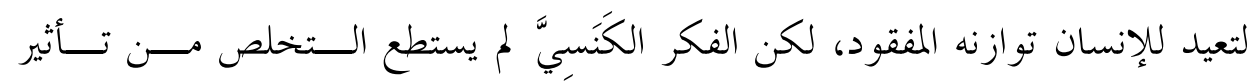

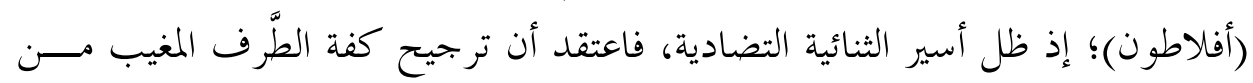

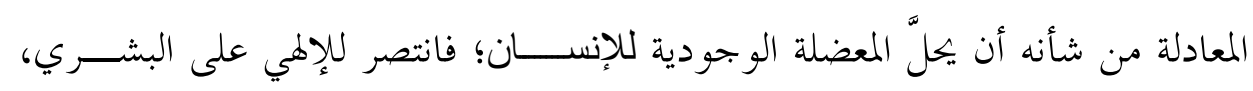

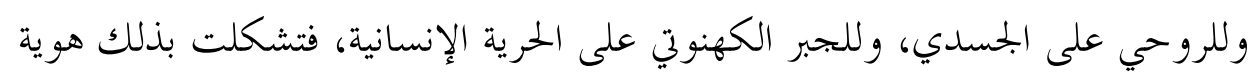

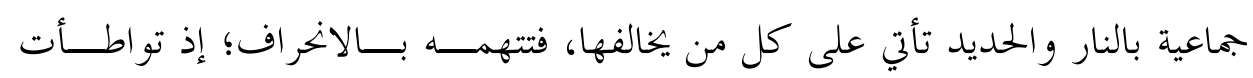

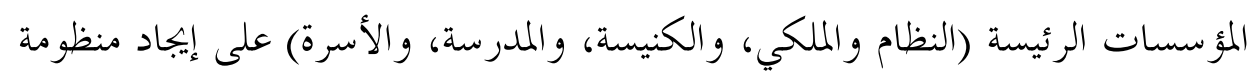

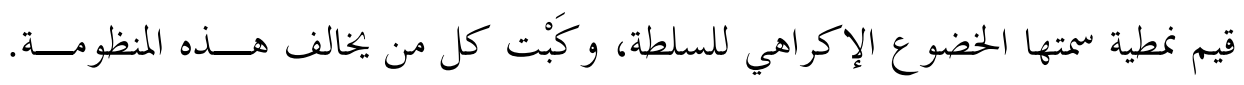

${ }^{8}$ Garaudy, Roger, Le testament philosophique, Albin Michel, Paris, 1989, p.387. 


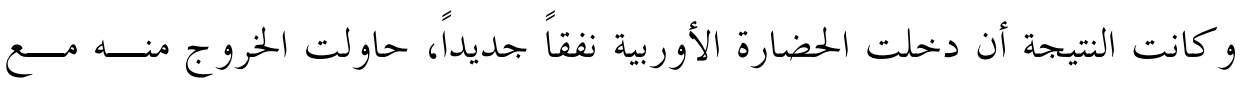

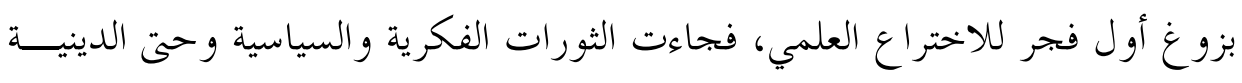

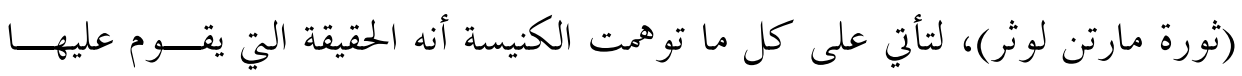

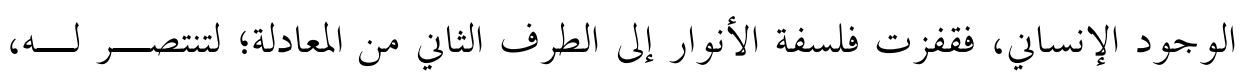
فأعلنت موت الإله وانتصار العقل.

لقد بنت فلسفة الأنو ارهُ هُيتها الفكرية على قاعدة أن التطور التكنولوجي مرادف

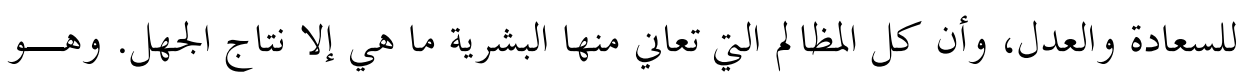

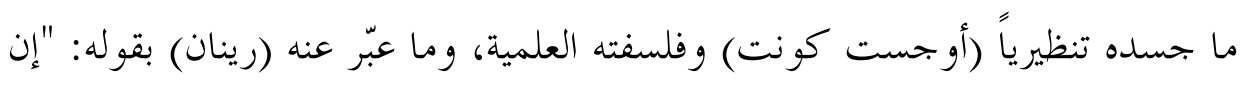

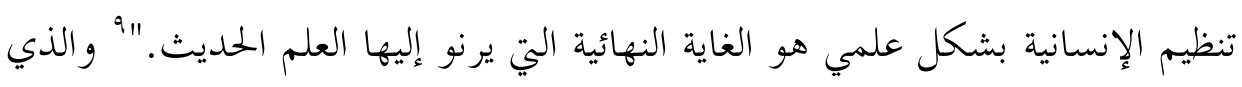

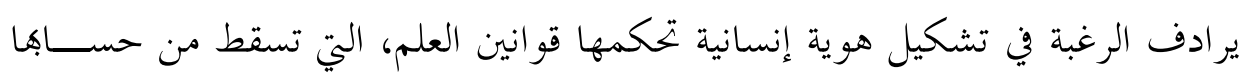

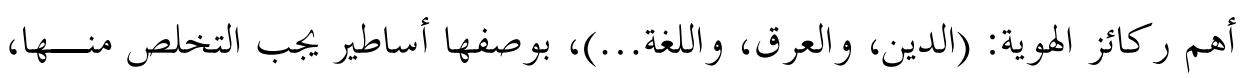

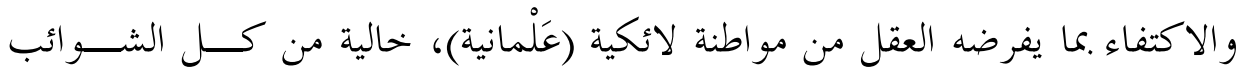

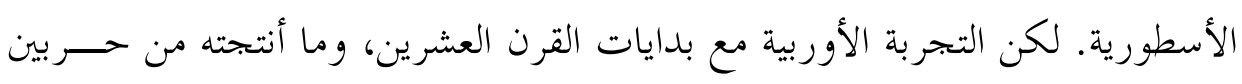
عالميتين مدمرتين، أثبتت محدودية هذا الادعاء وسذاجة الأيديولوجية العلمية. لم يخطر ببال فلاسفة التنوير، ومن حذا حذوهم من الحداثيين، أفم سيكونون في

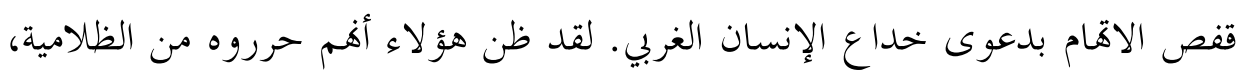

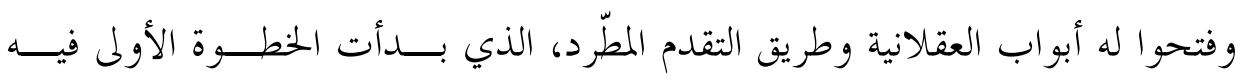

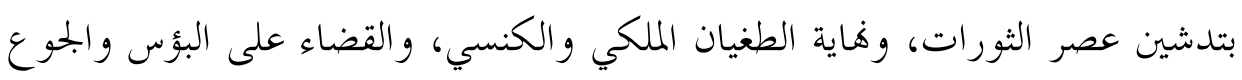

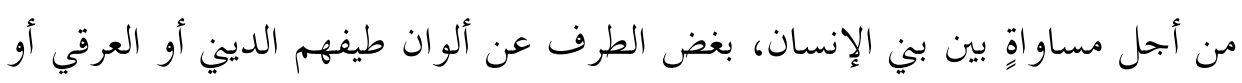

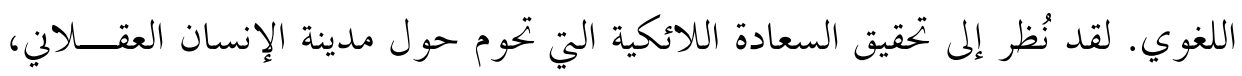

${ }^{9}$ Abastado, Claude, Introduction au Surréalisme, Paris: Bordas, 1986, p.15. 


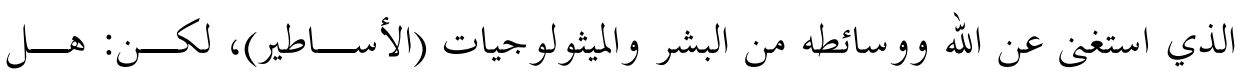

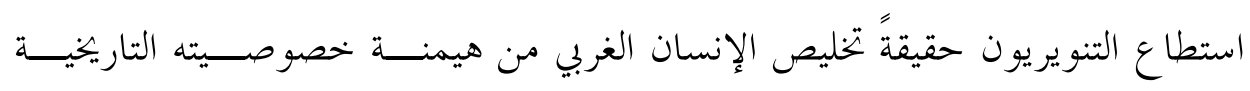

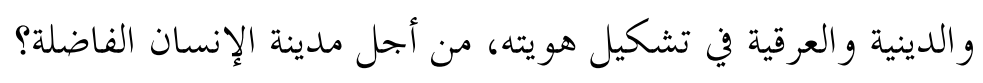

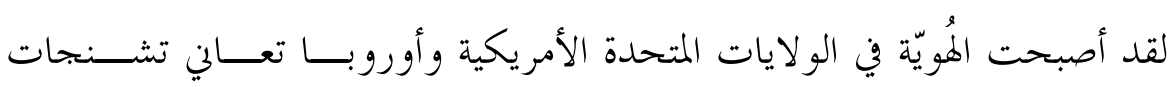

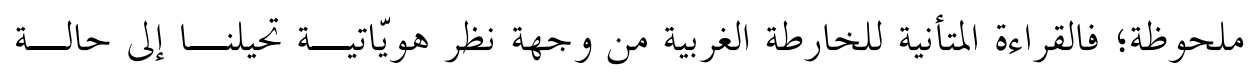

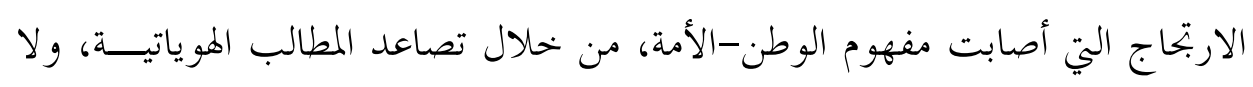

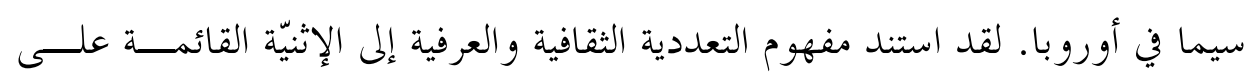

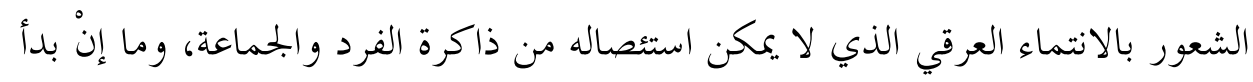

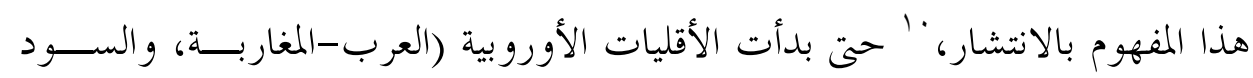

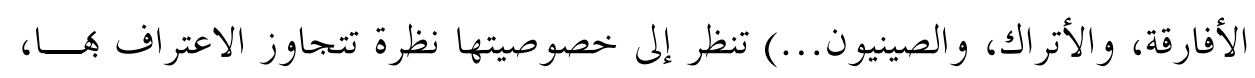

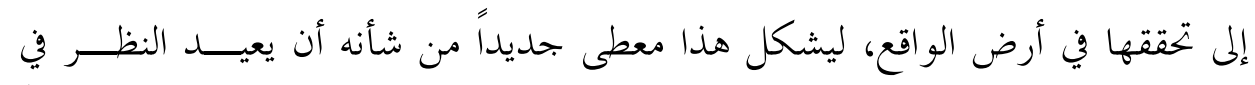
مفهوم المواطنة. ومن حينها شكّل الاعتداد بالجذور التاريخية و الثقافية للأقليات مُشكانلاً

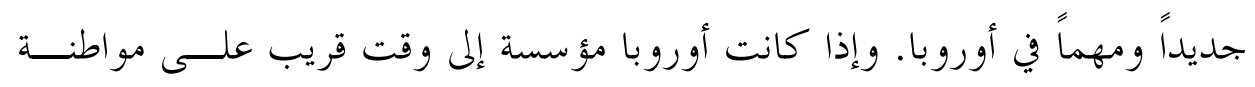

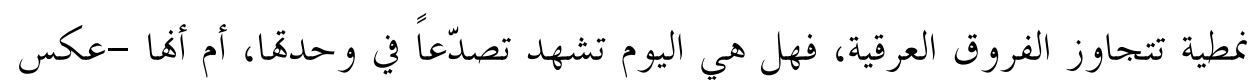

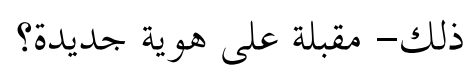

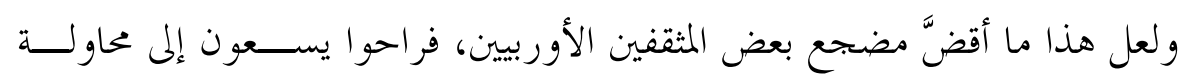

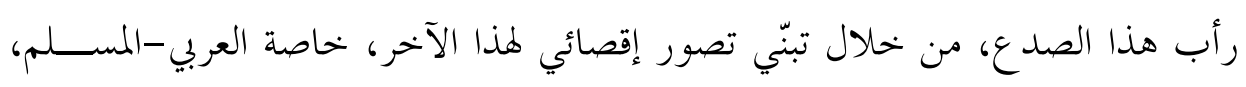
ما يجفظ لهذه الهوية تماسكها الأسطوري.

\section{ثالثاً: حضور الآخر الإسلامي في المخيال الأوروبي}

إذا حددنا هذا الآخر جغر افياً بالفضاء الإسلامي، بهكم انتمائنا إليـه، وتاريخيـاً الإنساً

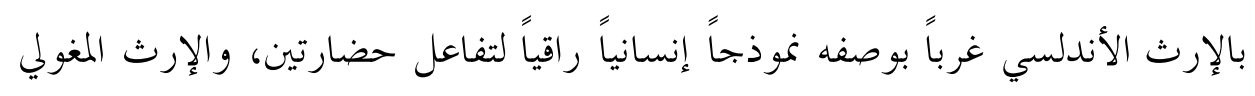

${ }^{10}$ Thual, François. Les conflits identitaires, Paris: Ellipses, 1999, p.58. 
شرقاً بعدّه ظاهرة حضارية تبين شغف الغالب باتباع المغلوب، و حاولنا تقييم حضـــور

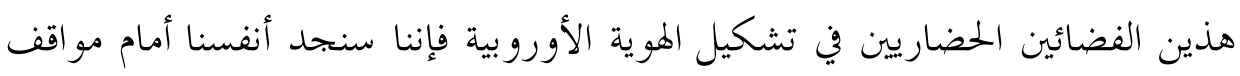
تتفاوت بين استهجان وطمس، لتنتهي إلى شيء من الاعتراف. ولنبدأ بدراسة موقف

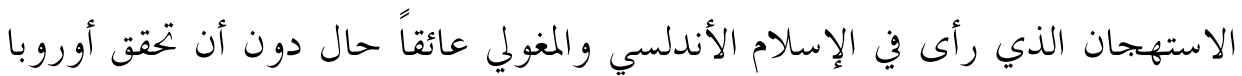
الناشئة ذاها.

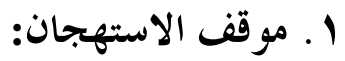

يمكننا أن نحصره في ثلاثة مواقف لرجال لهم باع طويل في محاولة التأسيس لعلموية المعارف الإنسانية، ألا وهم: المؤرخان (فرناند بروديل) و(هنري بيرين)، وعالم الإنسان الأنثربولوجي (كلود ليفي ستروس).

\section{أ. Fernand Braudel (فيرناند بروديل):}

في كتابه "خو" الحضارات" الموجه أصلاً إلى طلبة الثانوية، ويُعدّ كتابــاً (تربويــاً) بيداغوجياً بالدرجة الأولى، يتعرض (بروديل) إلى اللحضارة الإسلامية ومدى مساهمتها

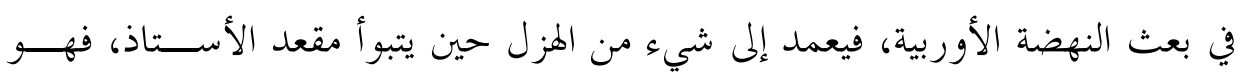
يوزع الدرجات و الملاحظات على بعض الإسهامات العلمية العربيــة، كالبصـــريات

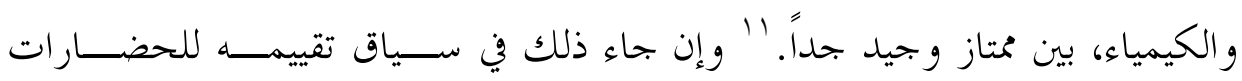
الإنسانية، إلا أنه يخفي موقفاً مركزياً ونرجسياً يطل من خلاله على على ما حققته الحضارة

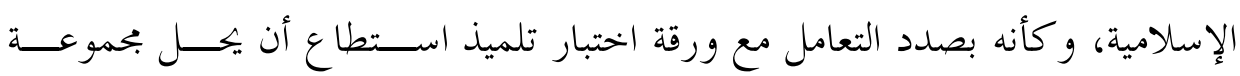
معادلات رياضية بذكاء ومهارة. وهذه النظرة تعزز التوجه نهو تفخيم الأنا الأوروبي،

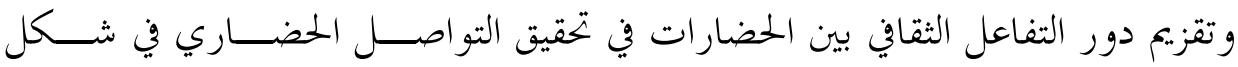
دورات تاريخية، وحصر بيان التقدم الإنساني في عامل تاريخي -جغرافي محدود بأوروبا.

${ }^{11}$ Braudel, Fernand. Grammaire des civilisations, Paris: Flammarion, 1993, p.113. 
إلا أن العطاء الإسلامي الأندلسي ومساهمته في تحرير العقل الغربي من هيمنة الأسطورة

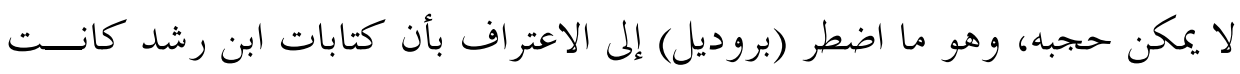

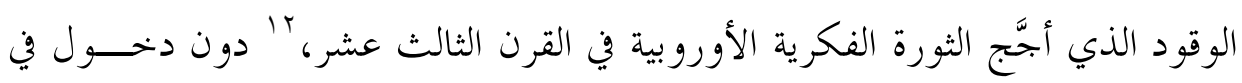
أي من التفاصيل.

وقد قسّم المؤلف كتابه هذا إلى فصول، و كل فصل خخصــص لحضــارة معينــة،

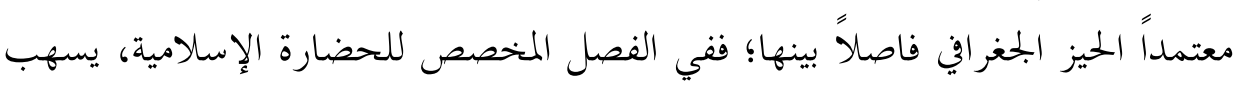

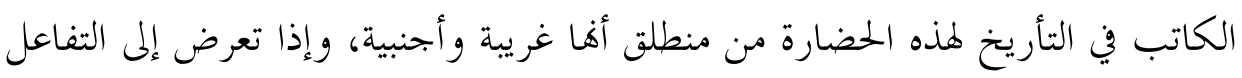

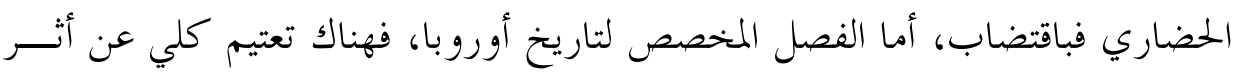

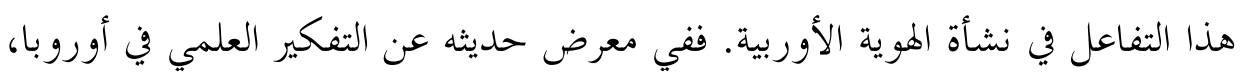

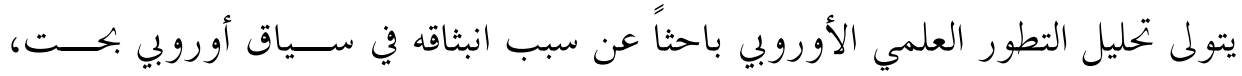

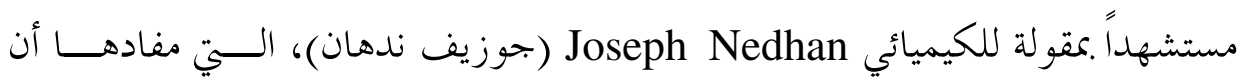

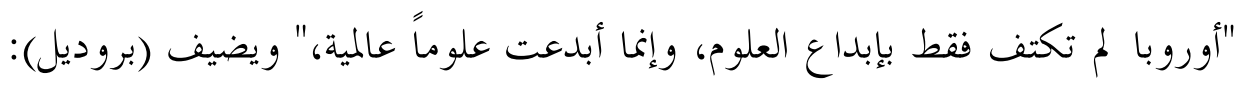

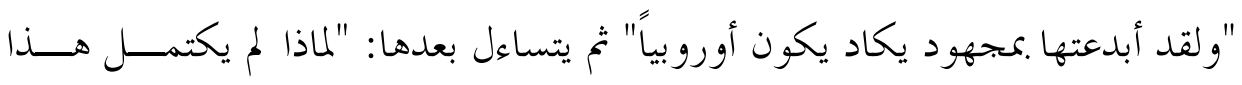

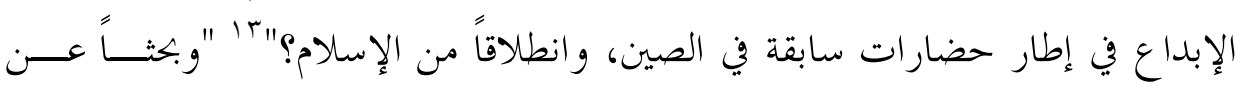

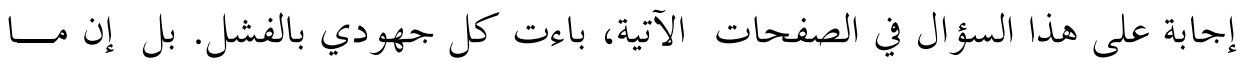

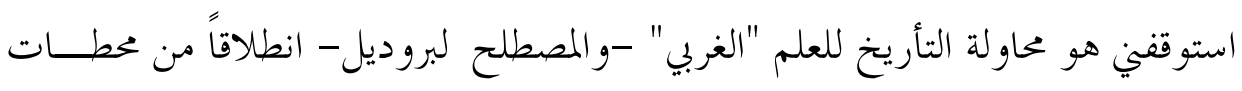

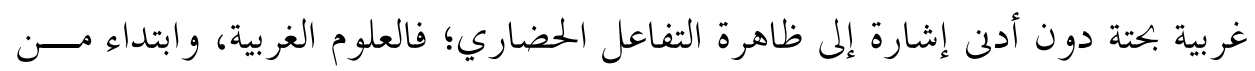

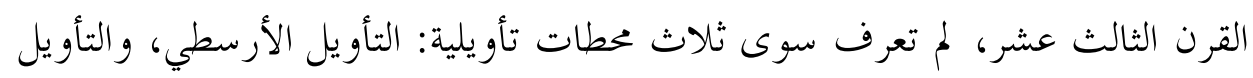

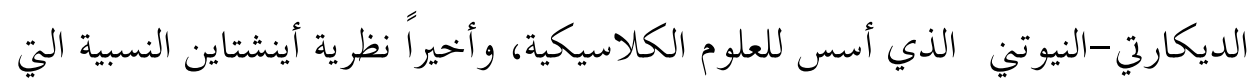

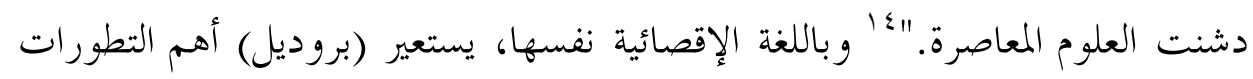

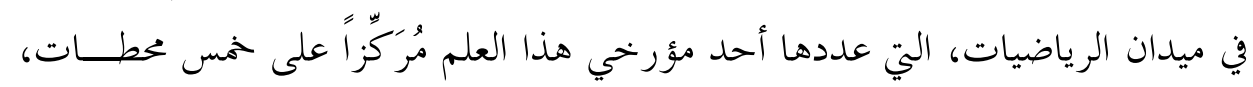

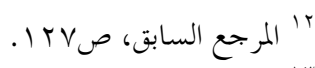

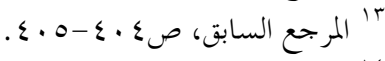

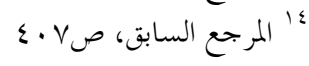




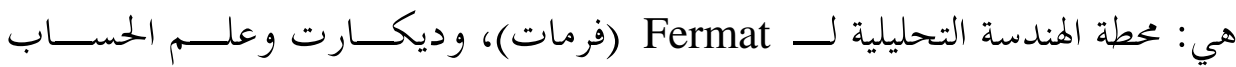

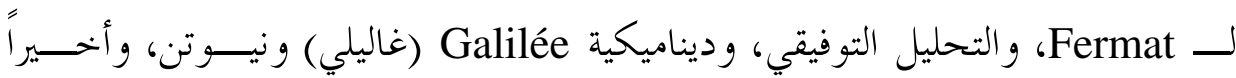

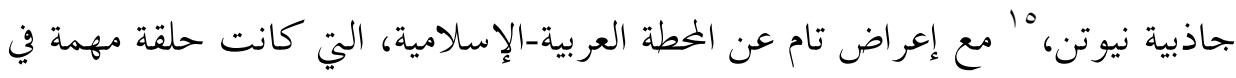

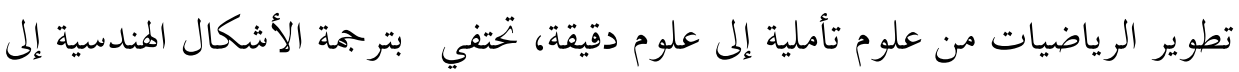

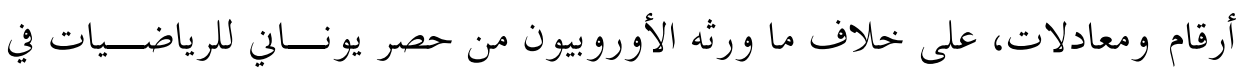

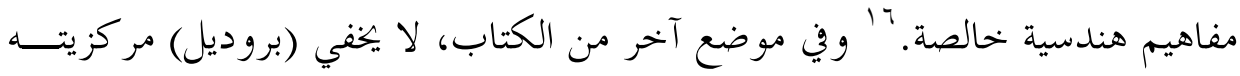

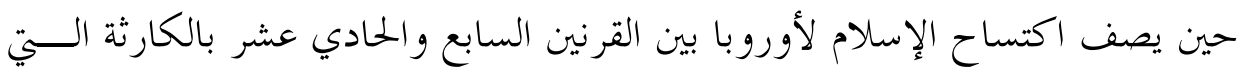

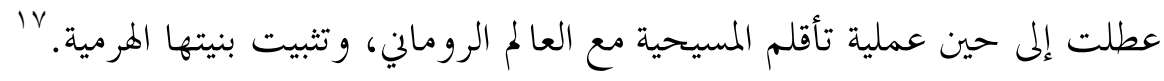
والسؤال المنهجي الذي يطرح نفسه بإلحاح: هل من حق الأكاديمي أن يتمتــرس

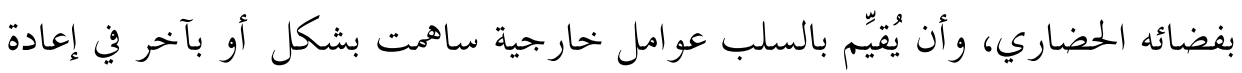

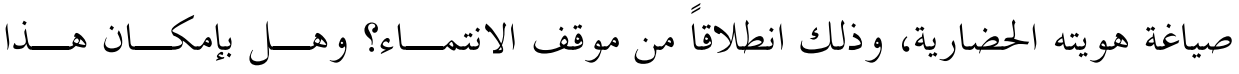

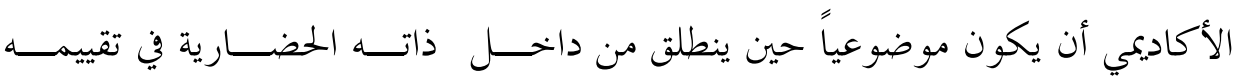

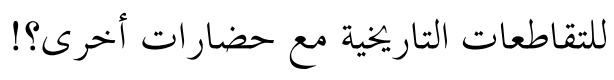

\section{ب. Claude Lévi- Strauss (كلود ليفي ستروس):}

و السؤال ذاته يمكن أن نطرحه على الأنثربولوجي الفرنسي (كلود ليفي ستروس)

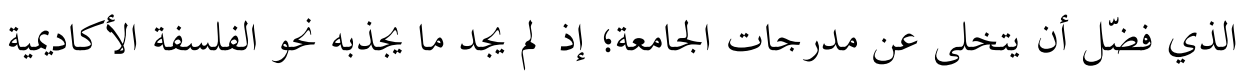

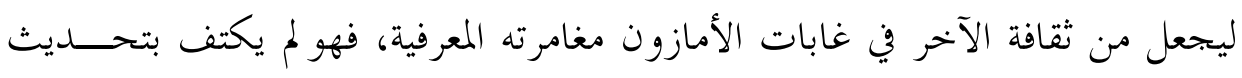

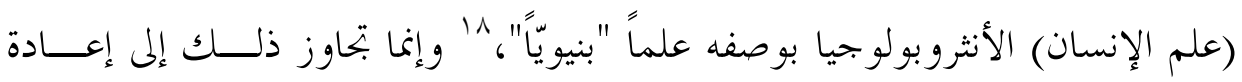

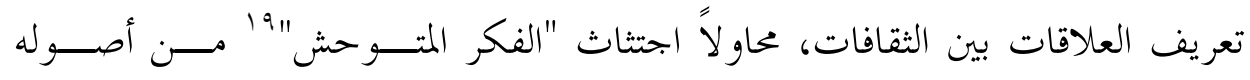

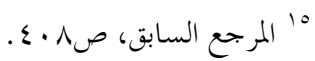

${ }^{16}$ Hunke, Sigrid, Le soleil, d'Allah sur l'Occident, Paris: Albin Michel, 1997, p104.

${ }^{17}$ Braudel, Grammaire, p375.

${ }^{18}$ Strauss, Claude Levy. Anthropologie Structurale, Paris: Plon, 1958.

${ }^{19}$ Strauss, Claude Levy. La Pensée Sauvage, Paris: Plon, 1963. 


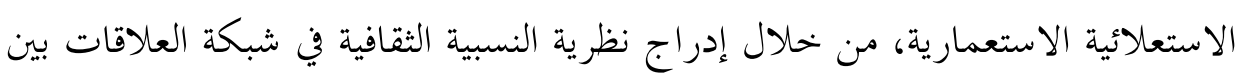

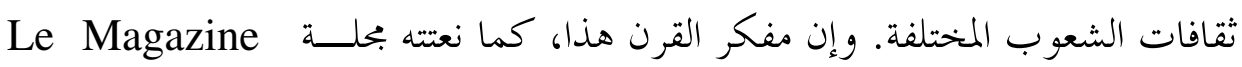
وLittéraire

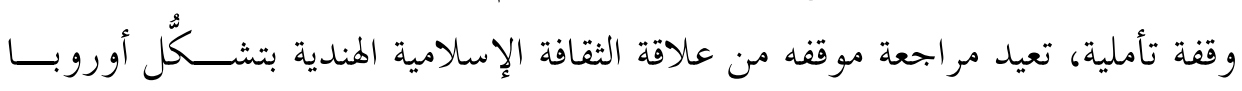

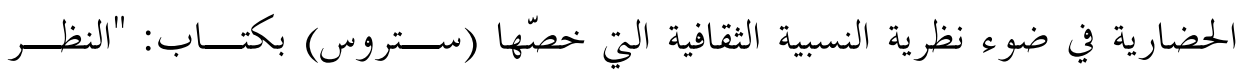

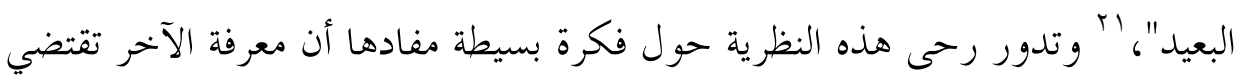

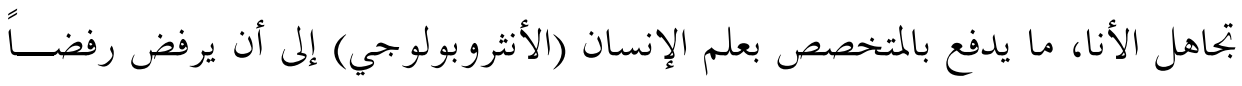

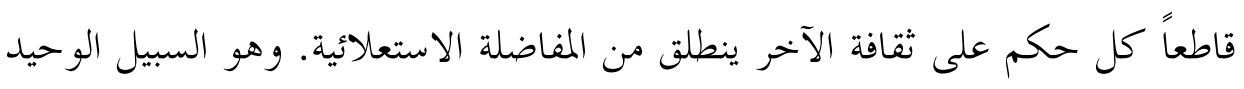

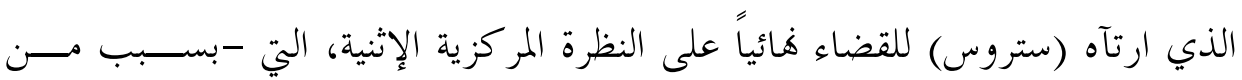

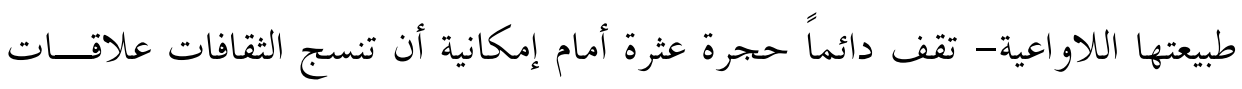

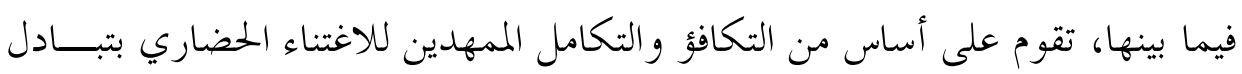

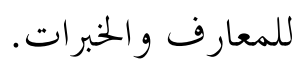

إن هذه النظرة المثالية في تناول ثقافة الآخر، التي جعلها (ستروس) كتابه المقدس،

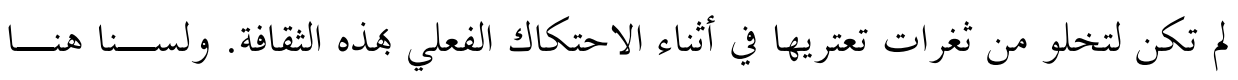
لنقاضي (ستروس) على تحامله على ثقافة الآخر، ولا لنتتبــع عور اتسـه في استقصــاء

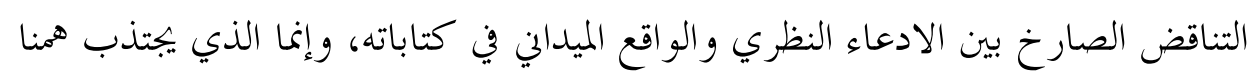

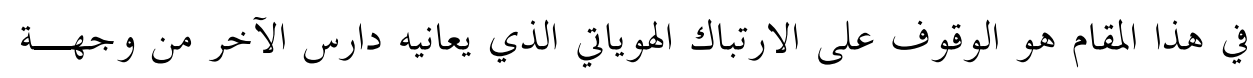

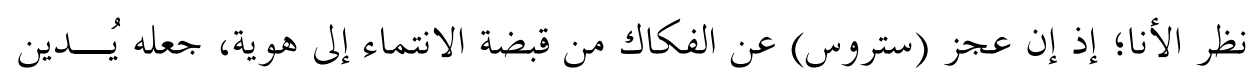

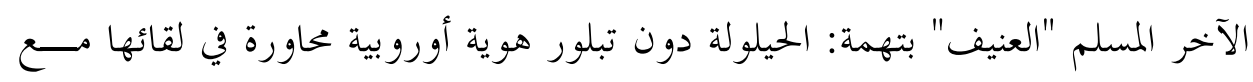

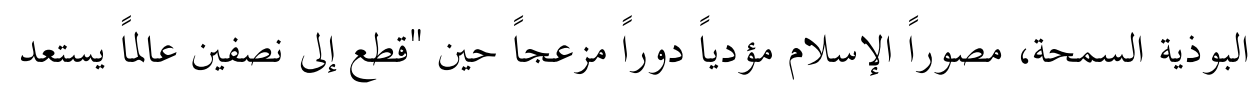

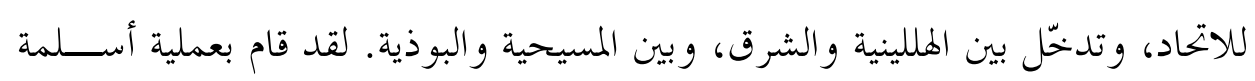

${ }^{20}$ Le Magazine Littéraire, $\mathrm{n}^{\circ}$ 475, mai 2008.

${ }^{21}$ Strauss, Claude Levy. Le Regard Eloigné, Paris: Plon, 1983. 


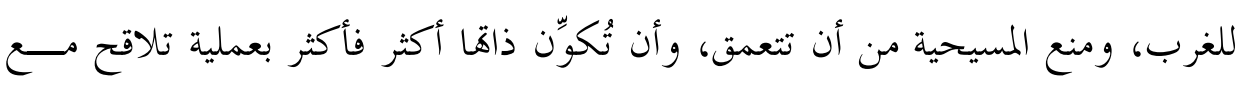

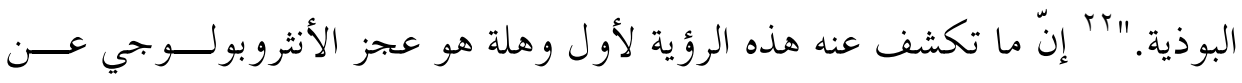
التخلص من الإنسان الذي يسكنه، ذلك الإنسان الذي استمد مبررات وجوده الهو ياتي من الجماعة التي فتحت عينيه على العالم. وعلى الرغم من انحيازية هذه الرؤية، إلا أها

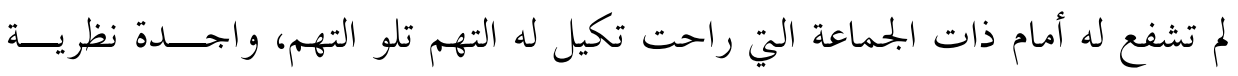

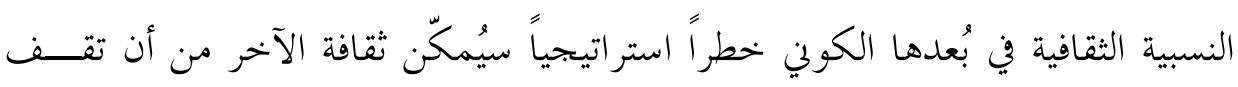
على قدم المساو اة مع ثقافة الأنا.

ليس غريباً أن يتعرض (ستروس) إلى حملة شرسة قادها بحموعــة مــن المــثقفين

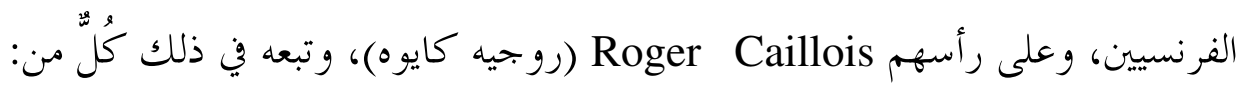
Maxime Rodinson Alain Finkielkraute

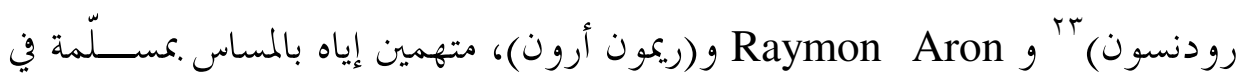

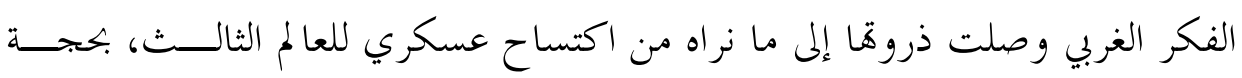

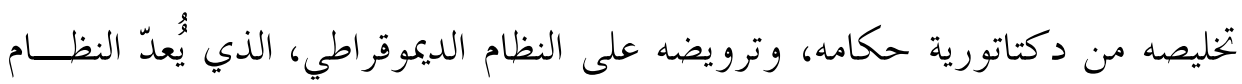
الأمثل لتسيير شؤون الإنسان في كل المعمورة، كما بشّر بذلك (فو كوياما).

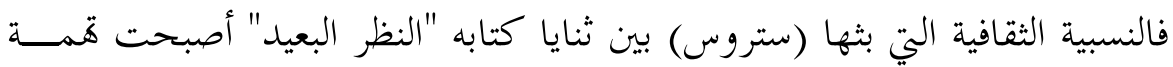

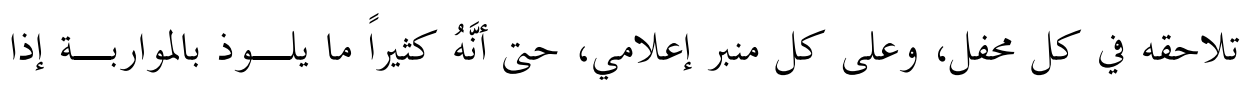

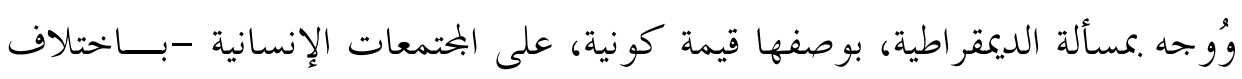

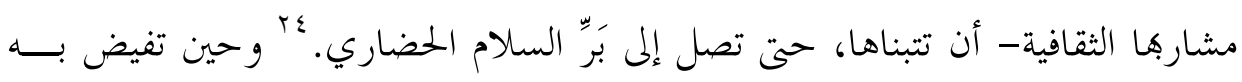

${ }^{22}$ Strauss, Claude Levy. Tristes tropiques, Paris: Pocket, 2002, p490.

${ }^{23}$ Strauss, Claude Levy. L'Anthroplogie structurelle, Agora: Pocket, 1995, p265.

${ }^{24}$ Strauss, Claude levy. De près et de loin, entretiens avec Didier Eribon, Paris: Odile.Jacob, 1988, p96. 
الكأس، فإنه يطلق العنان لقلمه ليرد بشراسة علــى مناوئسـهـ Roger Caillois؛ إذ لم

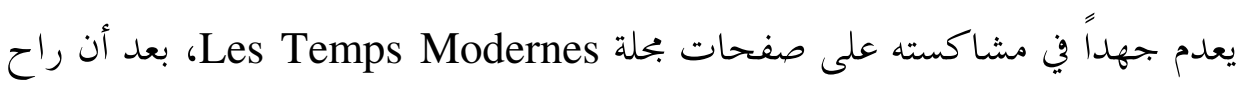

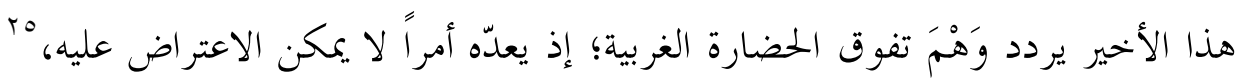

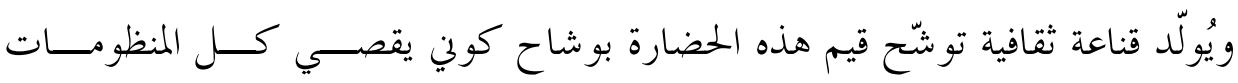

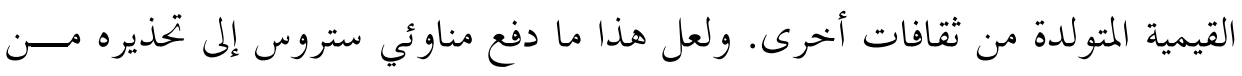

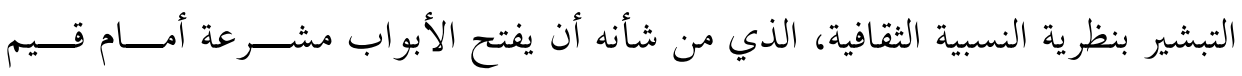

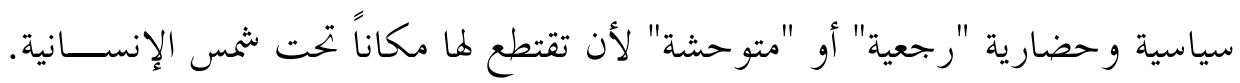

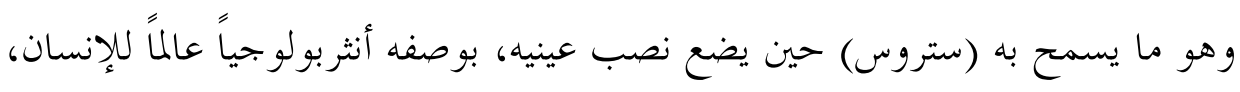
قاعدة أخلاقية تقضي بعدم المفاضلة بين الثقافات الإنسانية المختلفة. ولا ننكر أن هذه الحملة ومثيلاتها قد أفرزت إشكالية نفعية (براغماتيــة) تتعلــق

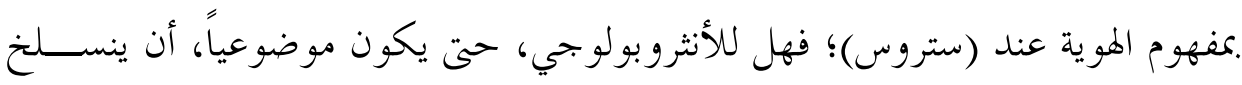

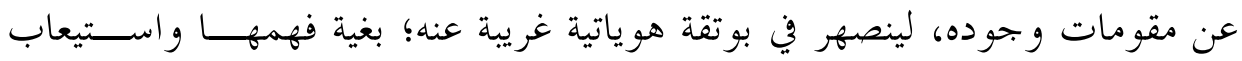

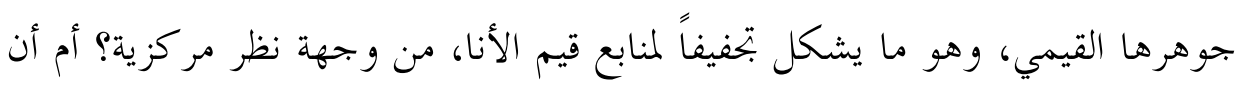

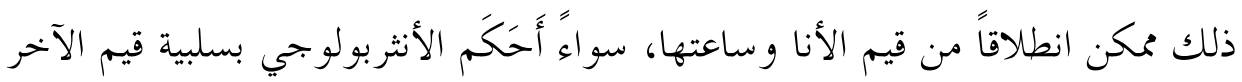

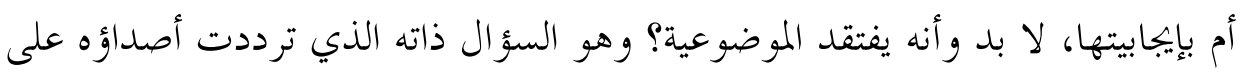

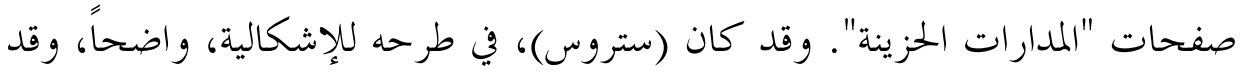

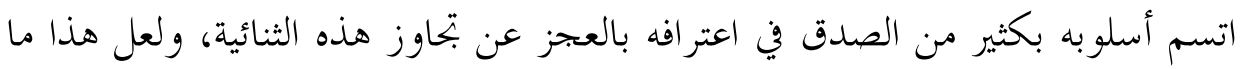

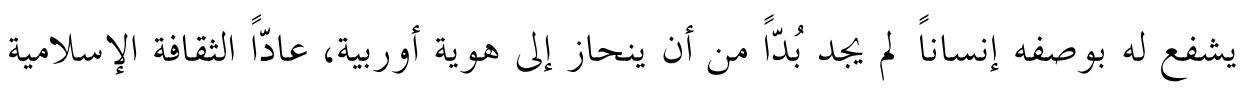
غريماً حال دون تواصلٍ بين البوذية والمسيحية، كان سيعود على البشرية بالخير لو قُدِّرَ

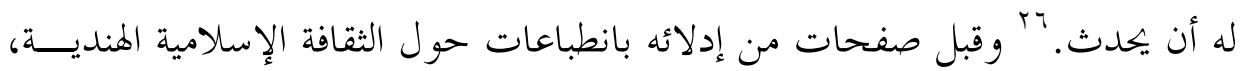

${ }^{25}$ Bollon, Ptrice. "La nouvelle querelle des universeaux", in Le Magazine Littéraire, op.cit, p82.

${ }^{26}$ Strauss, Claude Levy. Tristes Tropiques, Paris: Pocket-Plon, 2002, p490. 


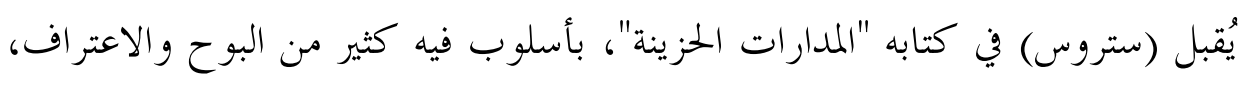

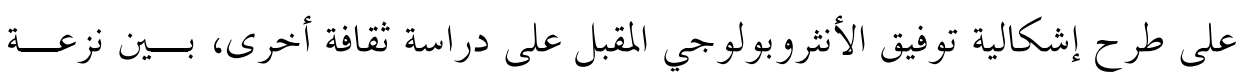

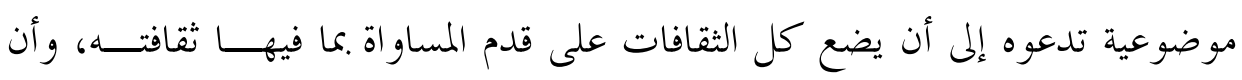

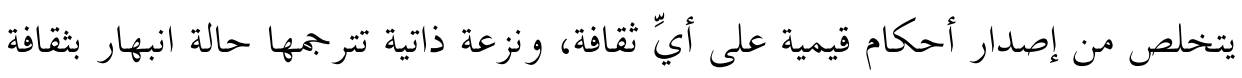

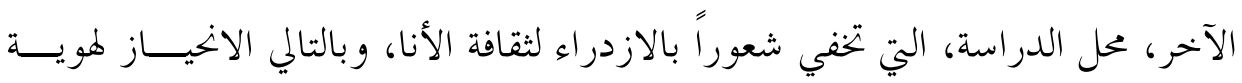

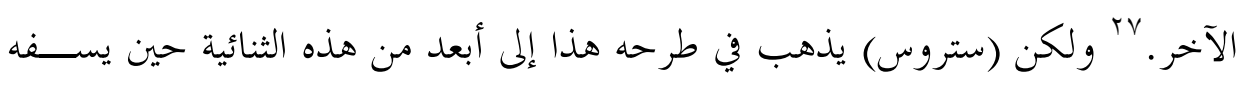

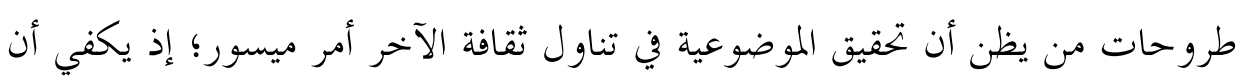

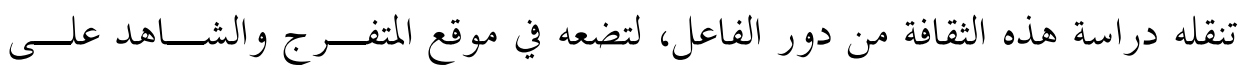

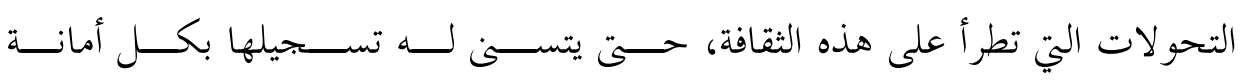

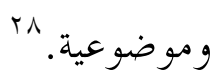

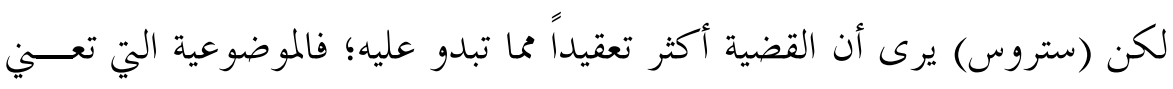

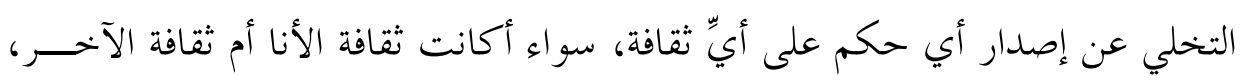

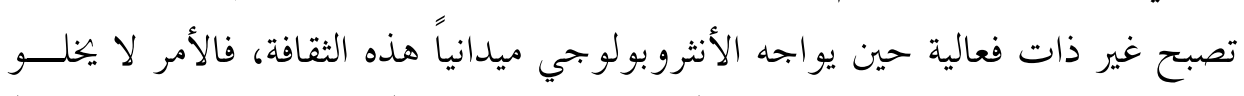

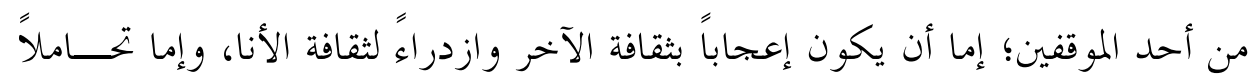

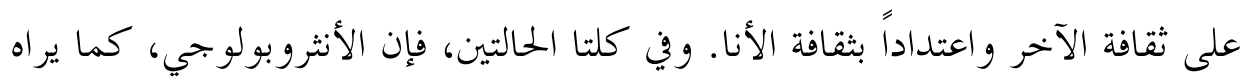

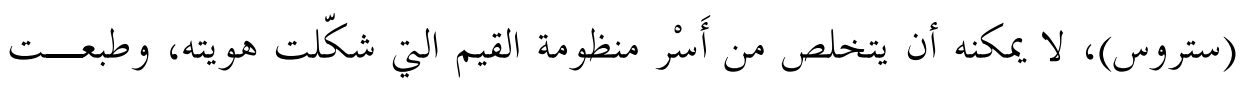

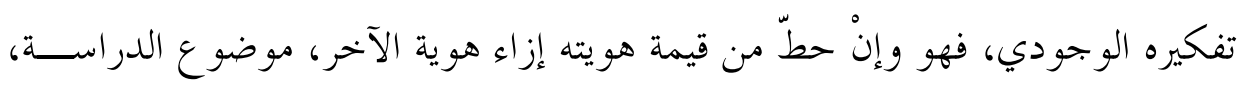

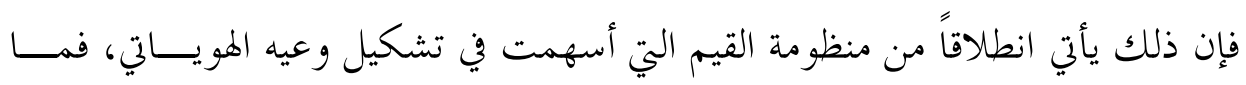

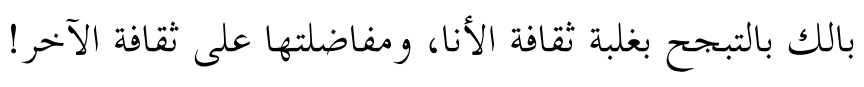

وعليه، يخلص (ستروس) إلى أن كل محاولة لمقاربة الثقافات المختلفة، مما فيها ثقافة

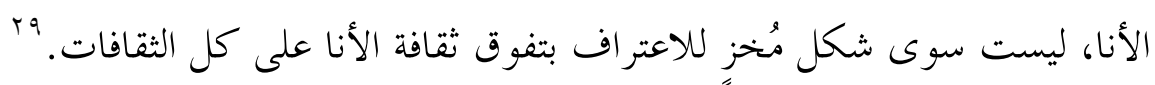

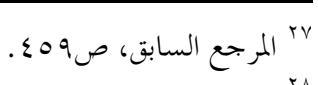

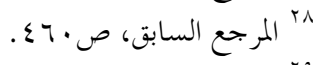

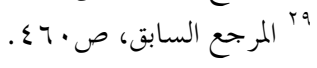




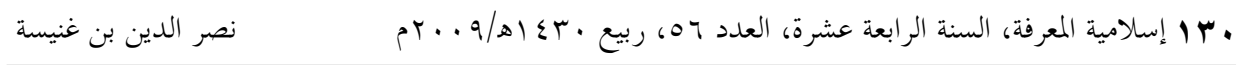

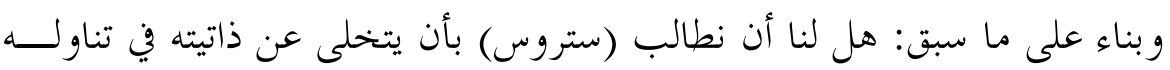

للآخر، بعد أن اعترف بالعجز الكلي عن الإفلات من قبضة البُعد الهوياتي في تشــكيل وعي الأنثربولوجي، وقبل ذلك الإنسان، بالعالمج وهل هذا الاعتراف يعفيه من النظرة التهكمية الساخرة، التي تناول من خلالها الثقافة الإسلامية الهندية، حين راح يختصــر

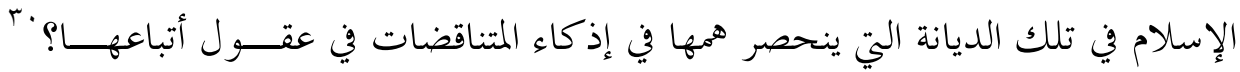
و "إذا كان هناك من سبيل لتخليصهم منها، فإن الإسلام يقترح عليهم حلو لاً في غايـــة البساطة"، ويضرب (ستروس) مثالاً على ذلك؛ إذ يخاطب المسلم قائلاً: "هل تتو جس خيفة من أخلاق زوجحاتك وبناتك حين تكون في الحقل؛ ليس هناك ما هــــ أســــل، ألبسهن الحجاب واحبسهن في البيت."ابّ وفي السياق ذاتِهِ، يتهكم من البُرقع الــذي

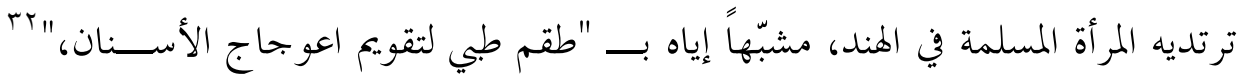
مختزلاً مشكلة المسلم في الهوس الجنسي؛ إذ لا همّ له سوى "عذرية المرأة قبل الدخلـــة

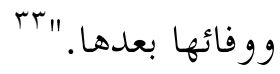

وفي موضع آخر من الكتاب، لا يجد حرجاً في المقارنة بين الهندوس والمسلمين في

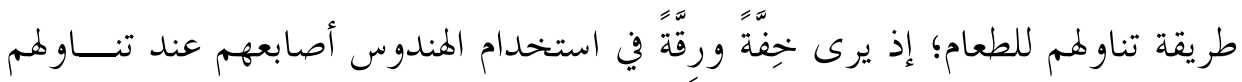
الطعام، بينما يتحول المنظر عند المسلمين إلى وساخة؛ إذ يهكم أن اليد اليسرى بخسة، فإن اقتصارهم على استعمال اليد اليمنى في نزع المضغة من اللحم وعجن اللقمة، جعل اليد اليمنى ذاتا الملطخة بالدهون تمسك بكأس الماء حين العطش. عَّليخلص (ستروس)

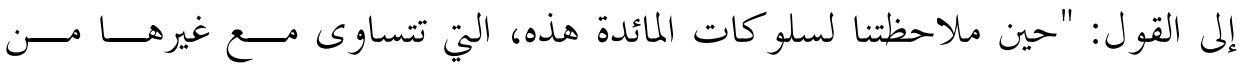

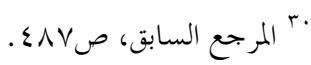

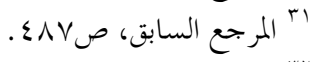

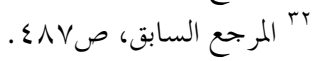

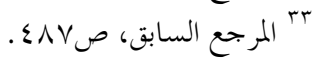

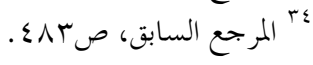


الكيفيات، إلا أها، من وجهة نظر غربية، تبدو كأها إبراز لطريقة تصرف مــنـ غـير

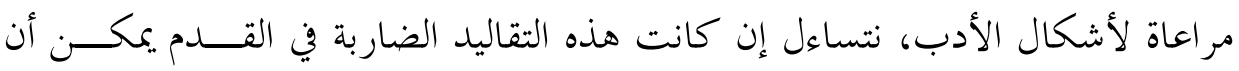
نعدّها نظرة إصلاحية ابتغاها الرسول القائل: (لا تفعلو ا مثل بقية الشعوب التي تأكــل

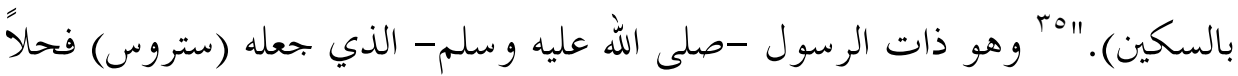

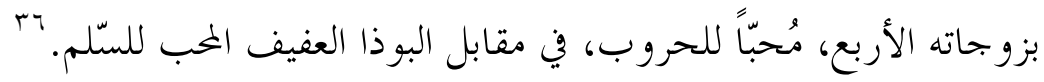

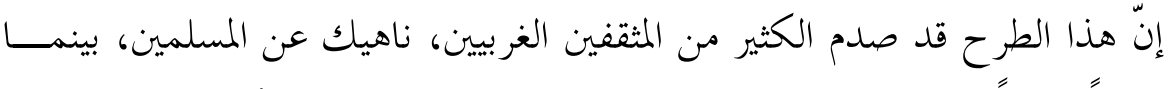

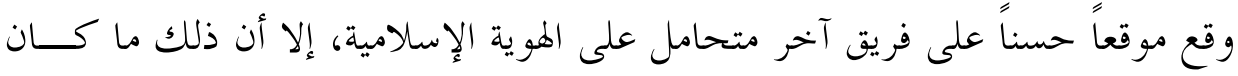

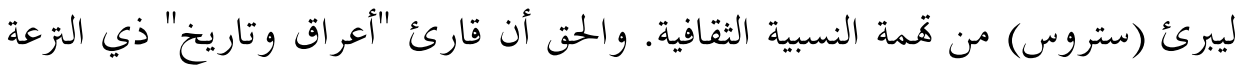

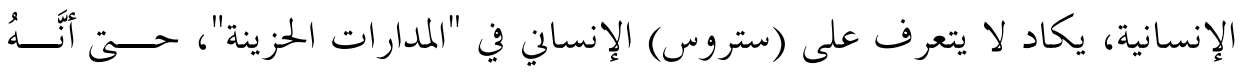
ليتشكك في نسبة الكتاب إليه.

ومرة أخرى: يجبُ ألا تطغى علينا مشاعر المظلومية التي تأسر صاحبها في اهزامية

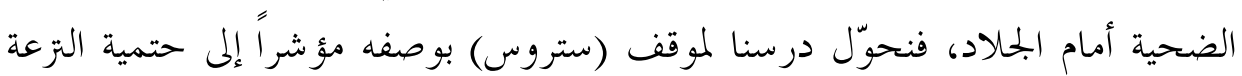

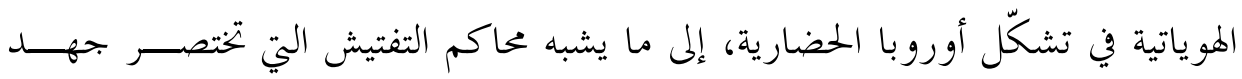

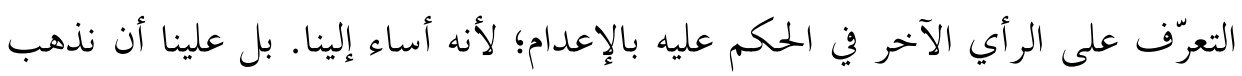

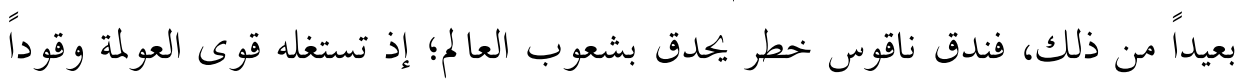

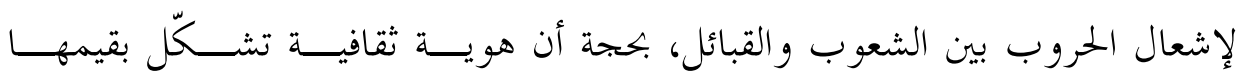

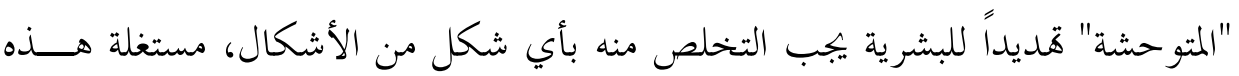

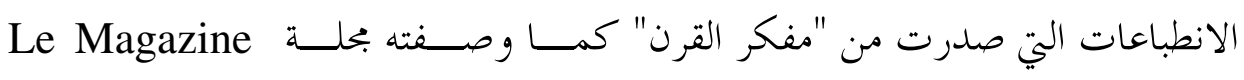

\section{.Littéraire}

ولأسف، فإن موقف (ستروس) يصب في ابتاه يغذي فكرة (هنتغتون) المخترعة

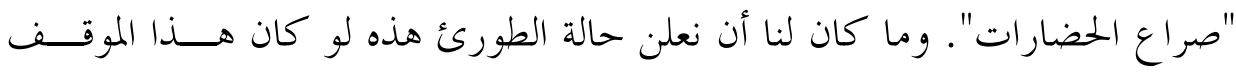

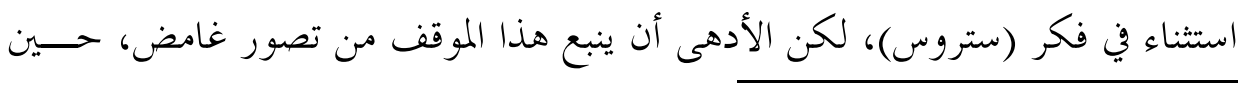

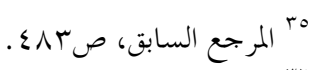

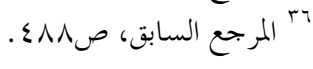




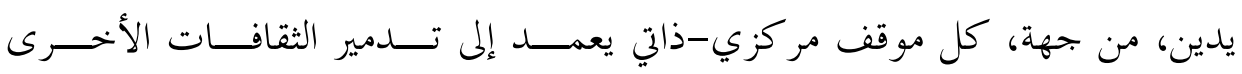

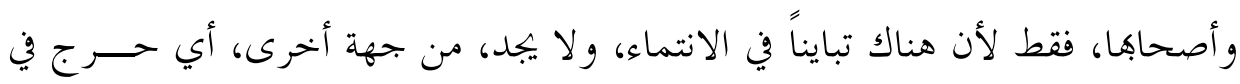

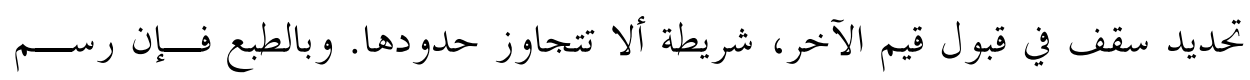

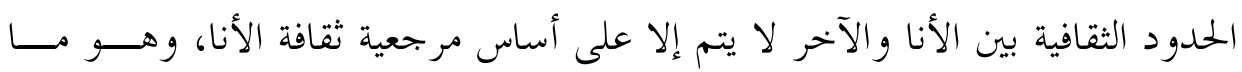

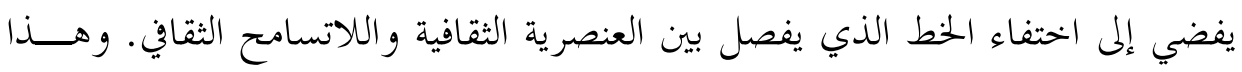

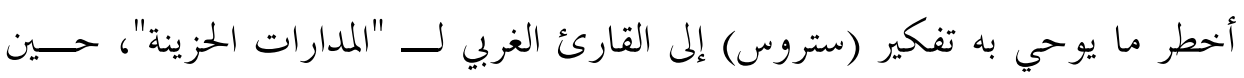

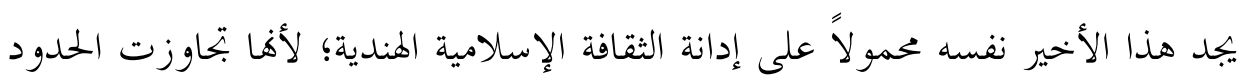

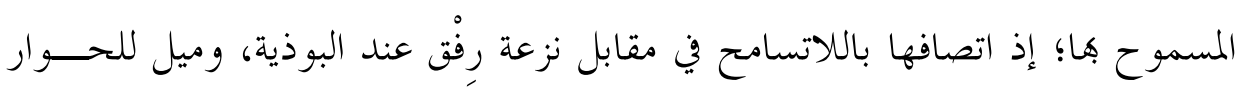

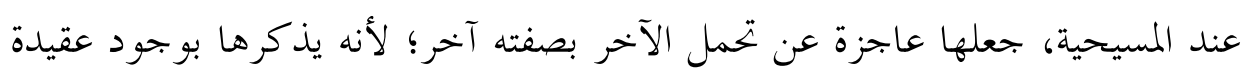

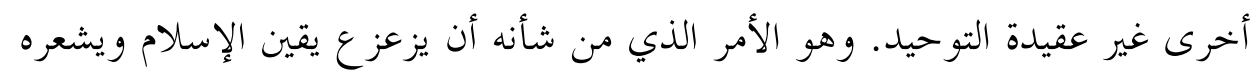

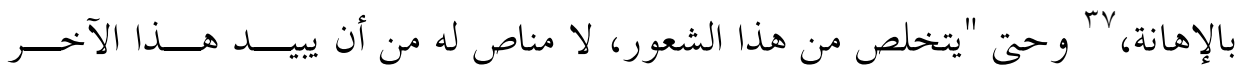

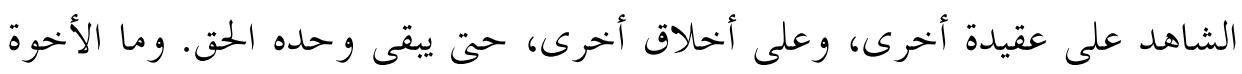

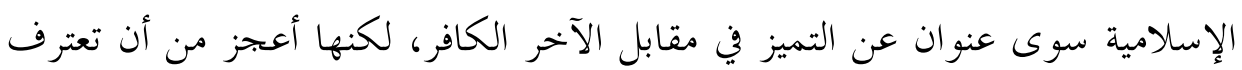

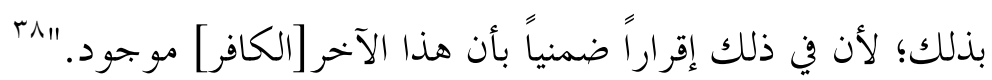

إن حدة هذه النبرة في شحن الإسلام بكل ذلك العنف، يمكن أن نعدّها ســابقة

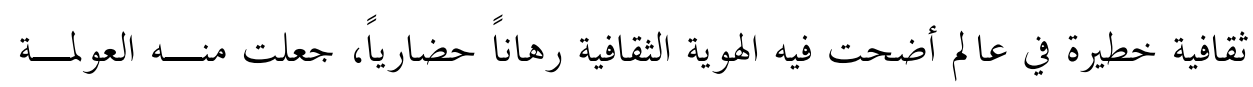
حصان طروادة تقتحم به حصون ثقافات الشعوب الأخرى؛ لتأتي عليها بحجة تمديدها

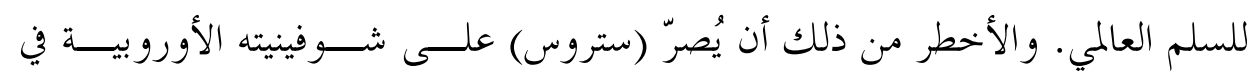

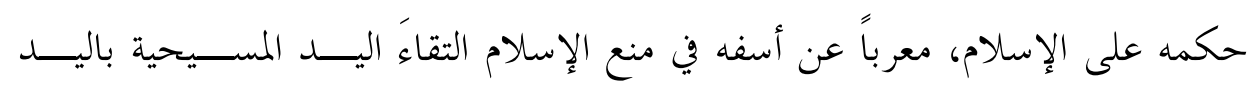

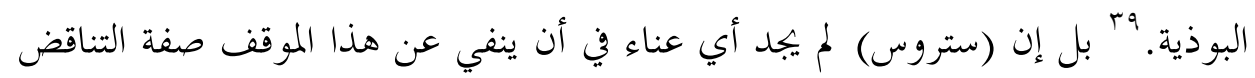

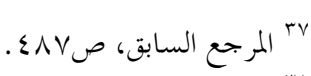

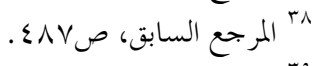

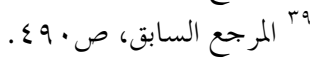


بين النسبية الثقافية والمفاضلة الثقافية؛ ليجعله ورقة تبرئة من قمة الميل إلى العرب، هذه التهمة التي و جهها له الفيلسوف الفرنسي من أصسـول يهوديــة Raymon Arond (ريمون أرون)، عقب هزيمة VT. وذلك في معرض إدانة (ستروس) لإبادة العرب مــن طرف إسرائيل على غرار إبادة الهنود الحمر؛ إذ لم يجد Arond مشــقة في أن يعيــبـ على ستروس محاباته العرب "الأعداء"؛ مما اضطر (ستروس) لأن يفصح عــن نفـــوره المتجذذر من العرب، وحتى يثبت حسن نو اياه راح يستعرض اعترافاتــهـ عــن الثقافـــة

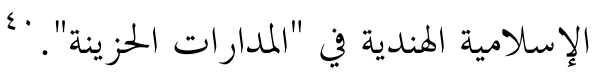

إنّ انتماء (ستروس) إلى هو ية ثقافية مثمّناً قيمها، من: لغة، و تقاليــــ، ومبــــادئ، وتصورات، أمر مشروع؛ إذ إن كل ثقافة وما تحويه من قيم هي ثراء معرفي وو جودي للإنسانية جمعاء، لكن أن يتخلى (ستروس) عن النظر إلى هويته بوصفها مركبة طبيعية

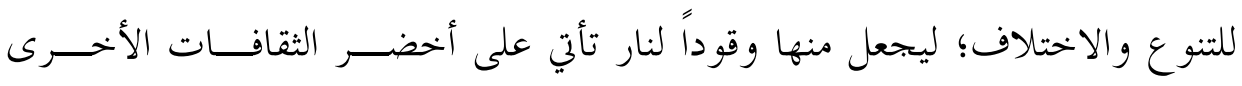

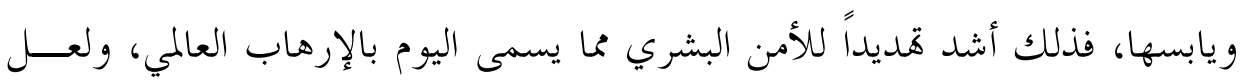
هذا الأخير يستمد مسوغات وجوده من هذه النظرة الإقصائية للثقافات الأخرى.

\section{ت. Henri Pirenne (هنري بيران):}

يؤسس المؤرخ البلجيكي (1935) Henri Pirenne في كتابه "عمد وشـــــارلمان" نظرية خلاصتها: إن الإسلام فكك الوحدة المتوسطية التي أسستها الهجمات الجرمانية

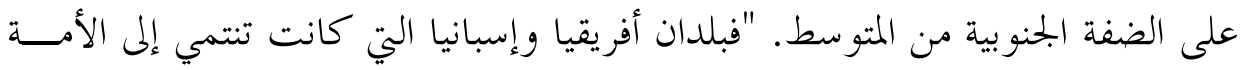
الغربية، تدور الآن في فلك بغداد. إنه دين آخر وثقافة أخرى اكتسحت كل ميـــادين الحياة. حتى يتحول البحر المتوسطي إلى بحيرة إسلامية، وتوقف عن دوره في أن يكون

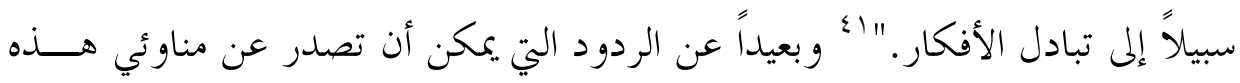

${ }^{40}$ De près et de loin, Op.cit, p.186

${ }^{41}$ De Libera, Alain. "Fractures en Méditérranée", in Manière de voir, n64, Juillet-Août, 2003, p1O-14. 


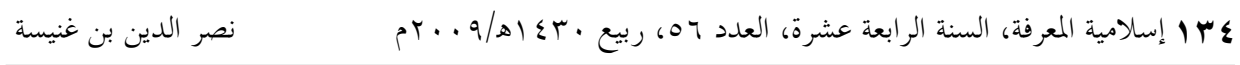

النظرية، فإنه بإمكاننا أن نقول: إن موقف الاستهجان هذا يوحي في أسوأ حالاتــهـ إلى ظاهرة التجاذبات الحضارية، فهو يؤكد على أن نشأة الأنا الأوروبية لم تتبلور إلا بفعل علاقة جدلية بالحضارة الإسلامية، و إنْ كانت في نظر هؤلاء سلبية. ومن هذا المنطلق،

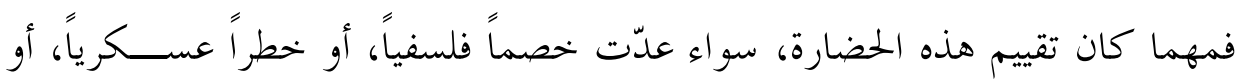

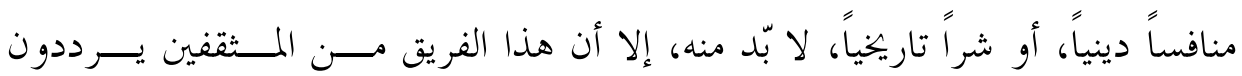

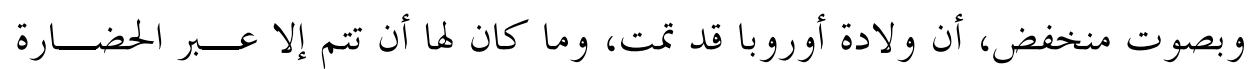

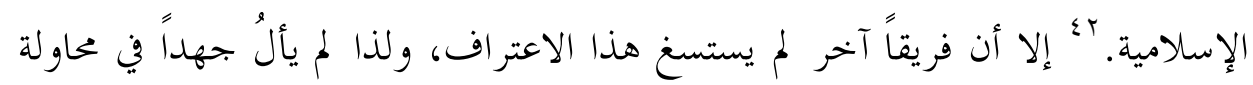

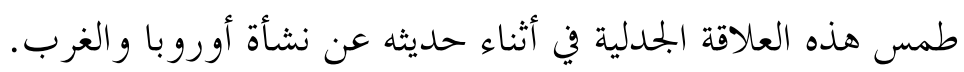

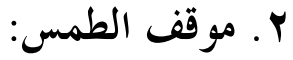

حاول بعض المفكرين والمؤرخين طمس الدور التاريخي للإسلام الأندلسي في نشأة

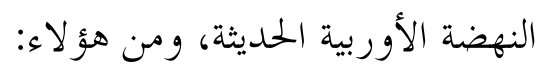

\section{أ. Gerard Leclerc (جيرار لو كلير):}

فقد أكّد في كتابه "العولمة الثقافية" أن مرور أوروبا من ثقافة تقليديـــة إلى ثقافـــة

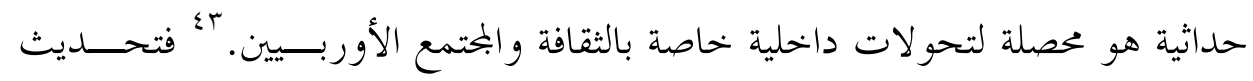
أوروبا كان عملية تحصيل لتفاعل بحموعة عو امل داخلية، وهذا النفي لتفاعل الثقافات يوحي بأن الحداثة الأوربية قد ولدت من فراغ؛ فهي لا تدين لثقافة الآخر بأي شيء، وكل إبخاز اتها إنما هي نتاج عبقرية حضارها، وهذه القطيعة الحضارية المفتعلة دفعــت الكاتب إلى تعزيز الحدود الوهمية، من خلال تكريس النظرة الثنائية (داخل -خهــارج) وذلك من خلال تعريفه للتغريب، بأنه عملية تحديث تتلقاها الحضارات غير الغربيــة على أها بحموعة أنماط حياة غريبة وأجنبية يجب أن تستبطنها. ؟

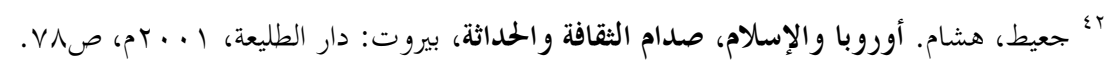

${ }^{43}$ Leclerc, Gérard. La mondialisation culturelle, Paris: PUF, 2000, p327.

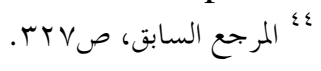




\section{ب. Max Weber (ماكس فيبير):}

عندما حاول (Weber) أن يجيب عن تساؤل يتعلق بعالمية قيم الحضارة الغربيــة،

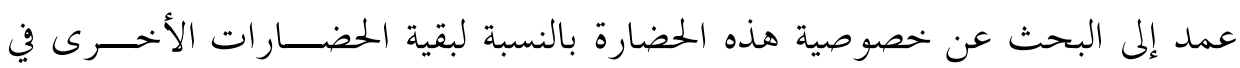
مرحلة ما بعد التنوير، فحصرها في تلك الحركية الثقافية الداخلية التي احتضنتها أوروبا وأفرزت العقلانية بوصفها أبرز ظاهرة حضارية عالمية، فراح يعلن أنه "خارج أوروبا، تظل العلوم و التقنيات عاجزة عن إقحام عقلانية الفكر و الثقافة، فهـــي في مراحلــــا الأولية؛ خارج أوروبا، لم نعثر على أثر للمنهج التجريبي والطب العقلاني والكيميــاء

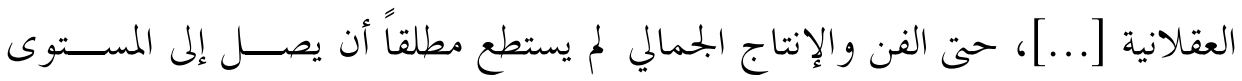

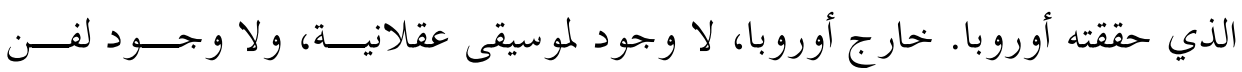

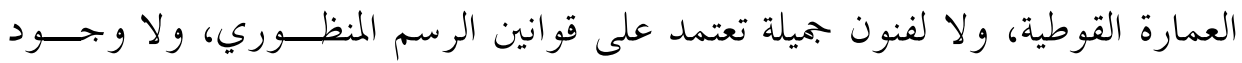

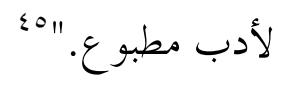

إن هذا التعداد لإبجازات الحضارة الأوربية الحلديثة في مقابل تقرير لعجز شبه كلي

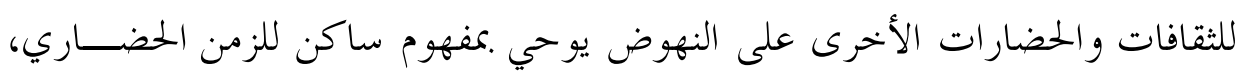
يتجلى في ضبط عقارب ساعة الصفر للحضارة الإنسانية ببداية عصر التنوير والثـــورة الصناعية. إلا أن هذا الطرح لم يعد يفي بالمهمة المنوطة به، التي تسعى إلى إبراز هويـــة أوروبية، ليس فقط بوصفها هوية تبزّ الهويات الأخرى، بل الهوية الأم التي أنارت العالم

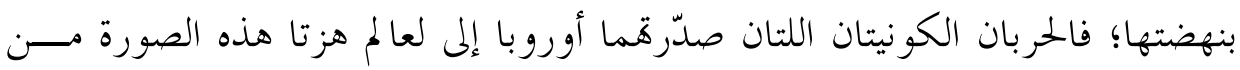

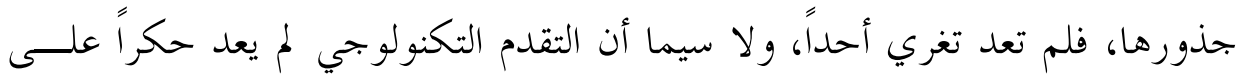
أوروبا بعد الحرب العالمية الثانية؛ إذ برزت إلى الوجود الولايات المتحدة الأمريكية في

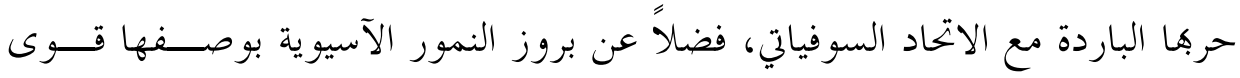

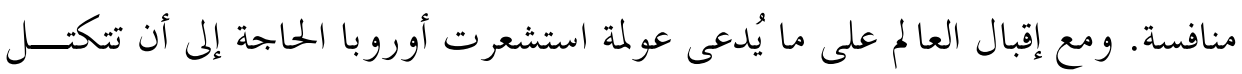
اقتصادياً في مواجهة التكتلات العالمية؛ فعاد هاجس الهوية يؤرقها من جديد. 


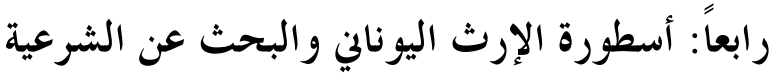

لعل أورو با اليوم في أمسّّ الحاجة إلى خطاب أيديولوجي جديد قديم حتى تُســـِّغ

اتحادها الاقتصادي في زمن العولمة، ولذا لا نعجب من لجوء الاتحاد الأوروبي، في بحثــــ عن هوية ثقافية تعطي شرعية لأورو با التكنوقراطية، إلى مجموعة من المؤرخين، حاثّــاً

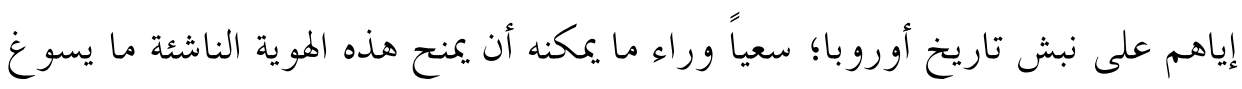
Sylvain تسويقها إلى العالم. ويف هذا السياق تــأتي كتابـــات المـــؤرخ الفرنســيـي Gouguenhein جبل سان ميشال، الجذور الإغريقية لأوروبا المسيحية" وهو خلاصة تراكمات أكاديمية تصب كلها في مشروع إعادة صياغة هوية أوروبية خالصة. فما إن صدر هذا الكتاب

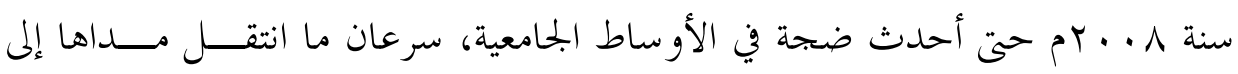
و سائل الإعلام.

و الحقيقة أن جهد الكاتب لم يتجاوز محاولة التوثيق لنظرية قديمة جديدة تــتلخص في قراءة تطهيرية للتاريخ الأوروبي تعيد الاعتبار للقرون الوسطى، بعدّها قرون تنــوير علمي؛ لتتخلص من مقولة انتقال الفكر الإغريقي عبر البوابة الفلسفية للترجمة العربيـــة

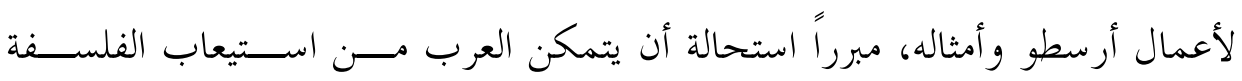
الإغريقية، وبحاوزها نحو تحرير للعقل من هيمنة الغيب؛ بسبب أن هؤلاء، و إن مَنَحُهــوا

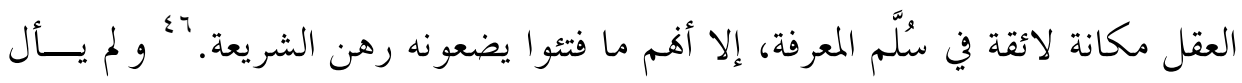

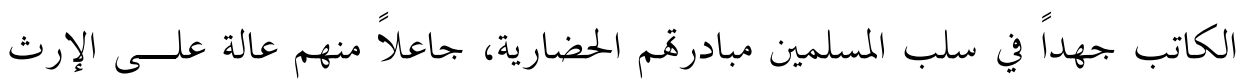
اليوناني و الإغريقي. وقد استجمع الكاتب كل جهده في حشد الأدلة والبراهين على ما ذهب إليه، والحق أن الموضوع يستحق وقفة من المؤرخين المسلمين وغير المسلمين من

${ }^{46}$ Gouguenheim, Sylvain. Aristote au Mont Saint Michel, Les racines grecques de l'Europe chrétienne, Paris: Seuil, 2008, p.165. 
يرون في ذلك إجحافاً في حق الإنسانية مثلة في بعدها الإسلامي، إلا أن الذي يعنينا في

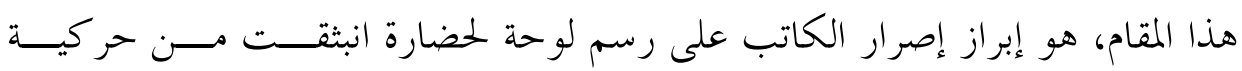

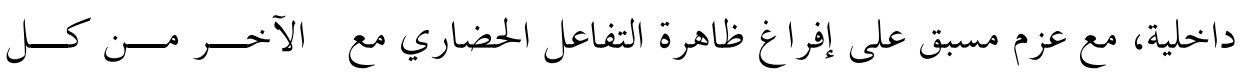
إيجابياتا.

لقد جاء هذا الكتاب تتويجاً لكتابات أخرى لمثقفين غربيين على مـــدى القــــنين

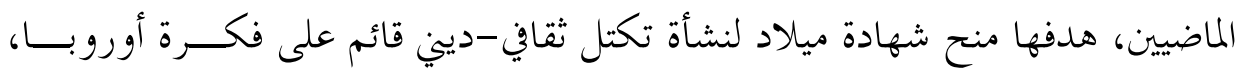

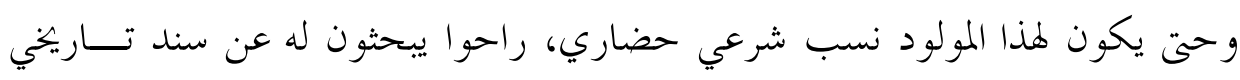

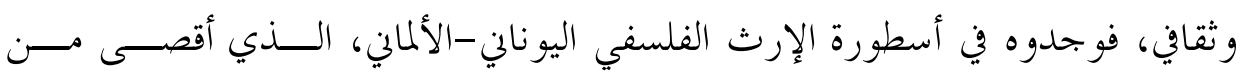

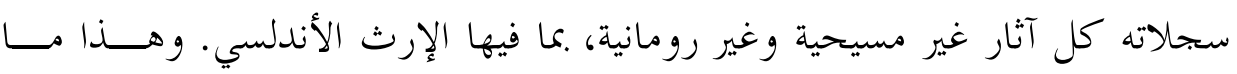

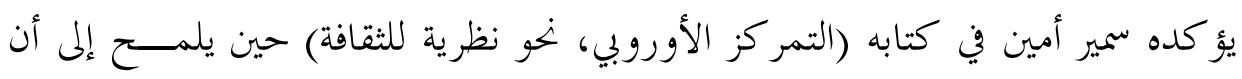

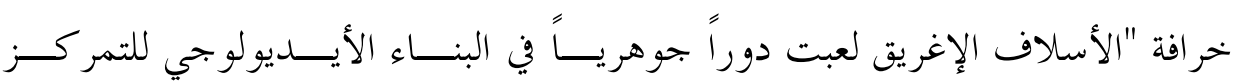

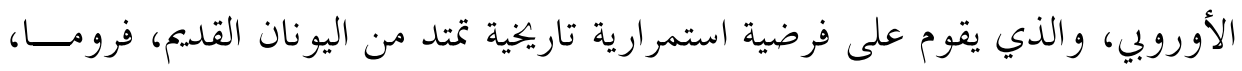

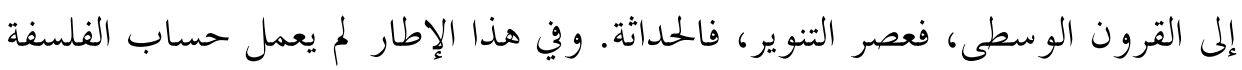

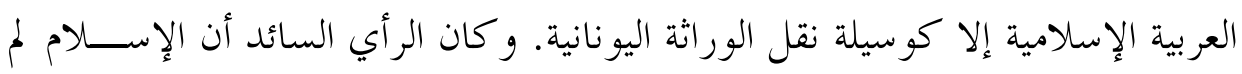

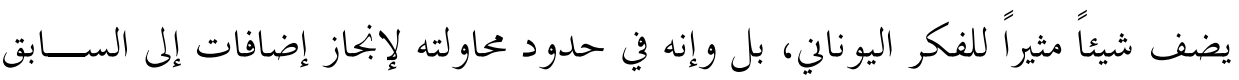

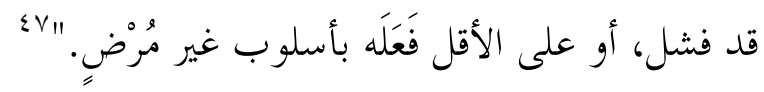

وفي مقابل موقف الطمس هذا، ننقل عن غربيين قولهم: إن الفلسفة الأندلسية هي

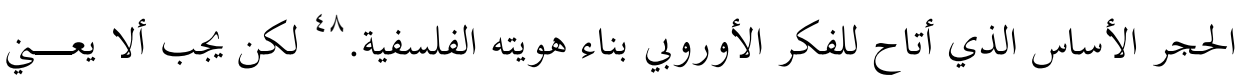

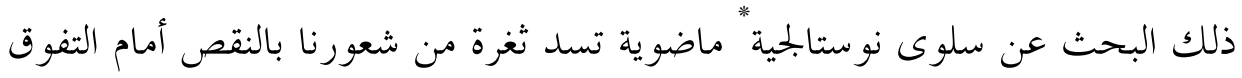

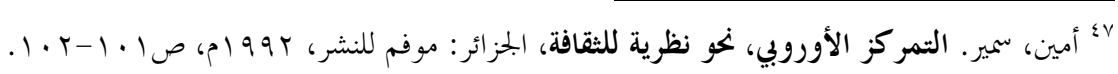
${ }^{48}$ De Libera, Alain, Autour d'Averroès, Marseille: Parenthèses, 2003, p13. 
الغربي، وإنما الذي يعنينا بداءة هو الكشف عن الحالة الاستثنائية التي فرضـــها التنـــوير الغربي على تاريخ العلاقات بين الحضارات، ألا وهي حالة التضاد والتقابل المفضي إلى الصراع والغلبة، التي بدأت بالانتقاص من فعالية الآخر في صياغة الأنا، وانتـــت إلى

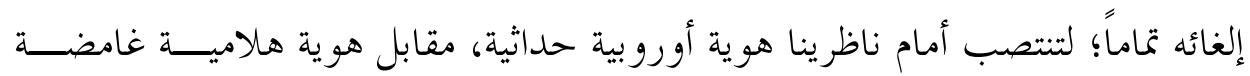
تدعى الفضاء الإسلامي. ومن منطق التضاد كان لا بد أن يوصف هذا الفضاء بكل ما يناقض الهوية الحداثية: كالتخلف، و الرجعية، والاستبداد، و التطرف، و القائمة لا تزال مفتو حة.

\section{خامساً: صورة الأنا في مخيلة الأنا}

حينما توعز الأنا الغربية لهذا الفضاء الإسلامي بأن لا مقـــام لـــه إلا في الحداثـــة

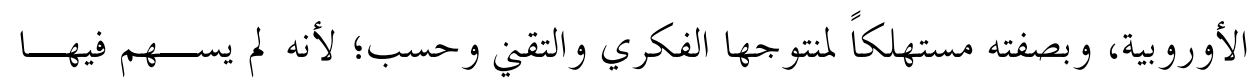
بتاتاً، فإها بذلك تكون قد صنعت لهذا والفضاء صورة الدخيل المغلوب؛ لتأخذ طريقها إلى الوعي الغربي في مقابل صورة الأنا الغالب. و الأدهى من ذلك أن المغلوب قد تبنّى

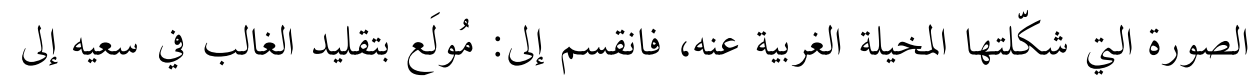

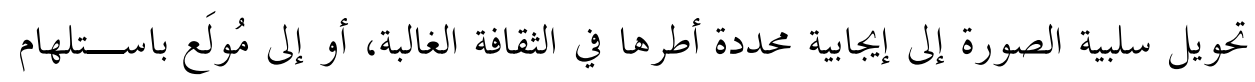
تاريخ غلبته ليصنع صورة ذاتية تستمد إيجابيتها من قراءة سلبية لصورة الآخر الغالب. و وعليه، فإن إعادة الاعتبار للنموذج الأندلسي يجب أن يتجاوز الرد على مــــقففي

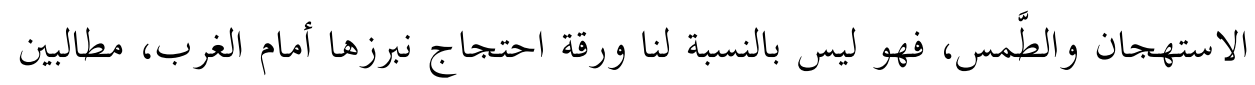

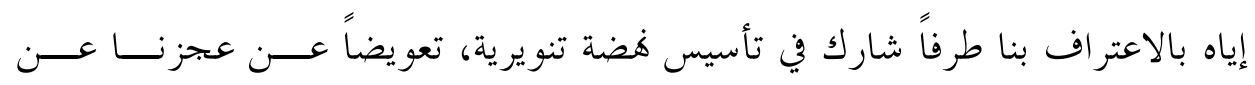

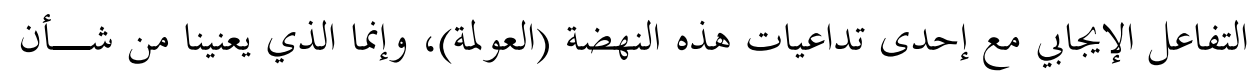

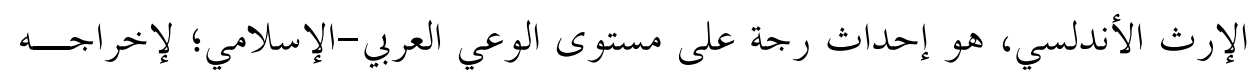

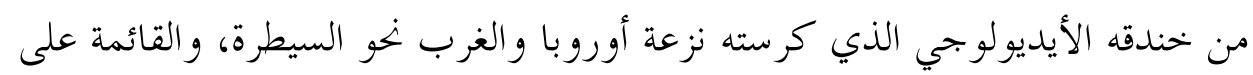
الفصل بين الأنا/الحداثي، و الآخر/الظالامي المتخلف. 


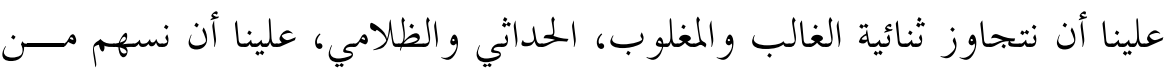

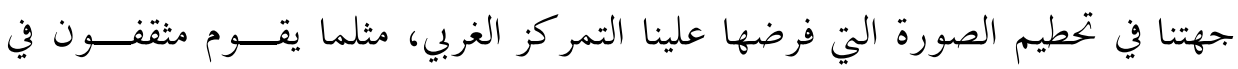
الضفة الأخرى من البحر المتوسط بتكسير هذه الثنائية: فها هو (جاك دريدا)، بصـــد

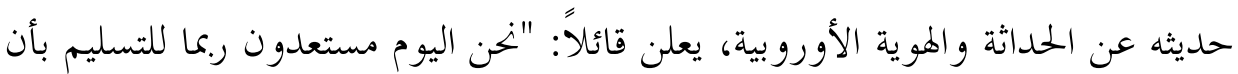

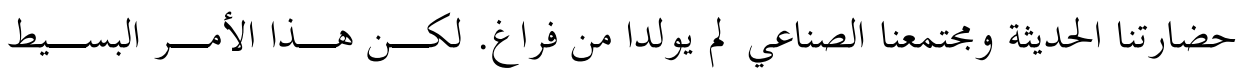

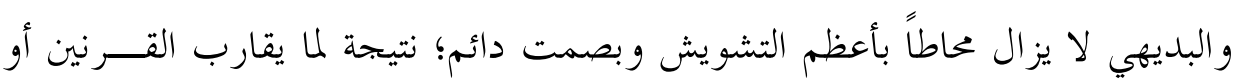

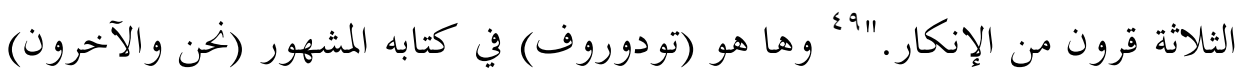

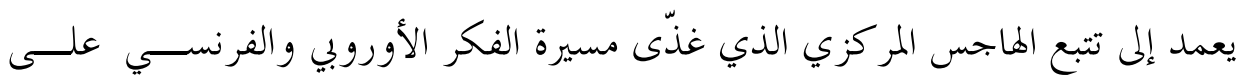

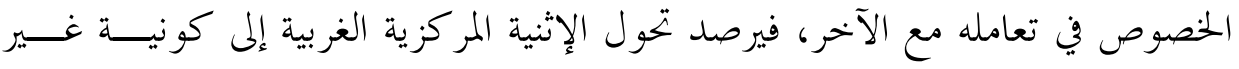

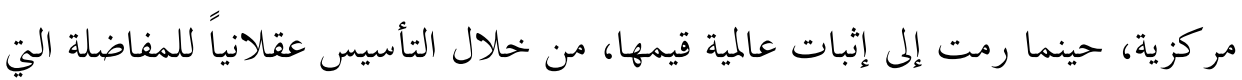

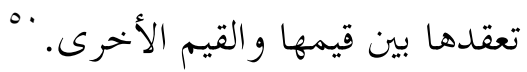

وهذا التجاوز للثنائية كان له الأثر في ظهور شريحة من المثقفين الغربيين تدعو إلى

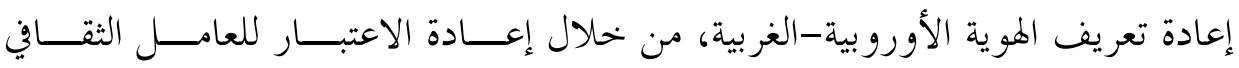

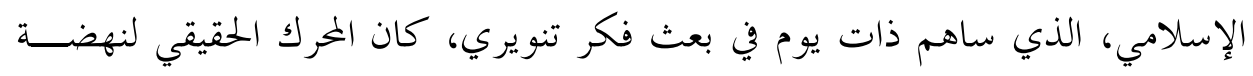

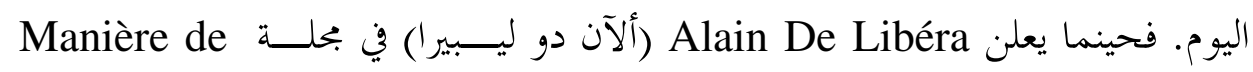

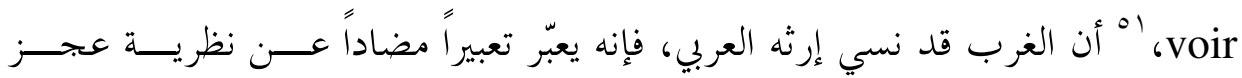

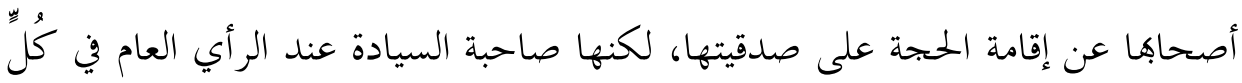

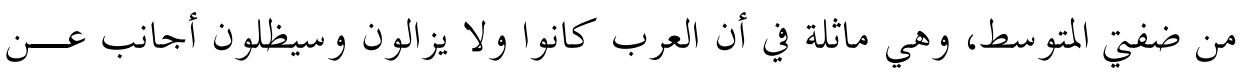

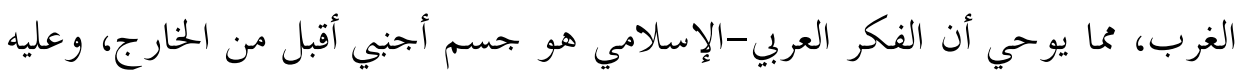

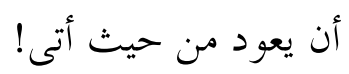

${ }^{50}$ Todorov, Nous et les autres, p22. 9؛ الشرقاوي، لقاء مع جاك دريدا، مرجع سابق، صعه.

${ }^{51}$ De libera, "Fractures en Méditérranée", p13. 
ويرى الكاتب أن هذا الرفض الواعي لهذا المركب الثقافي قد انغرس في الذهنيــة

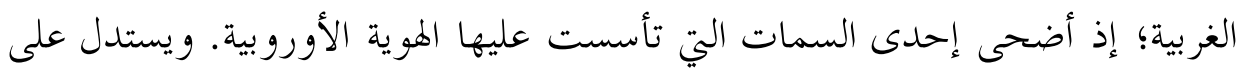
ذلك بالإقصاء الذي تمارسه المناهج العلمية في حق الإسلام المتوسطي؛ فجمهور الطلبة بيجهل كلية الفلسفة والعلوم العربية في العصر الوسيط. فالفلسفة الغربية المعاصرة لا تفتر

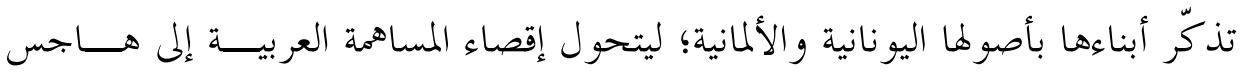

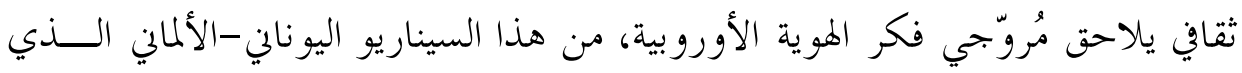

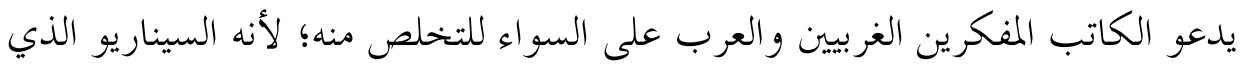

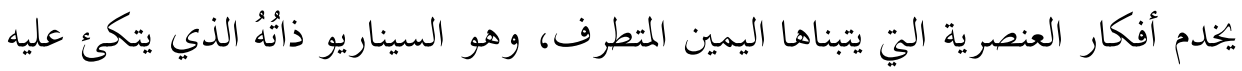

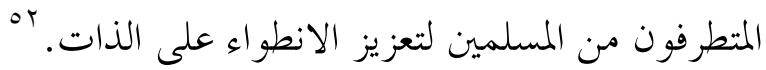

و الجحديد في الأمر أن هذا الصوت وأمثاله، يدعو إلى الحديث عن عناصر عربيــة-

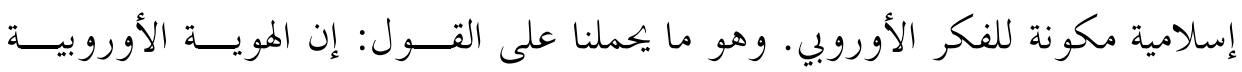

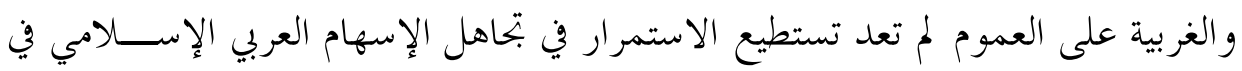

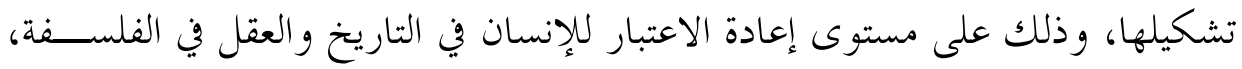

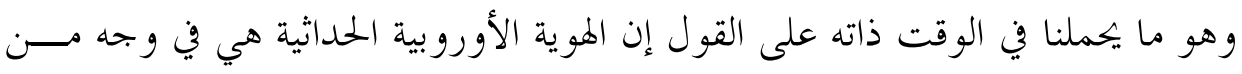

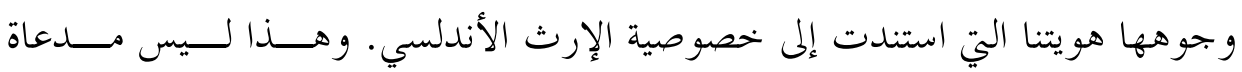

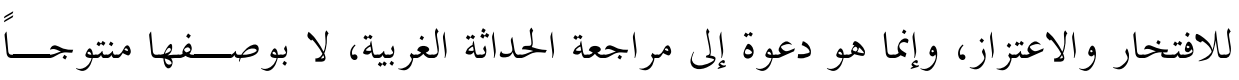

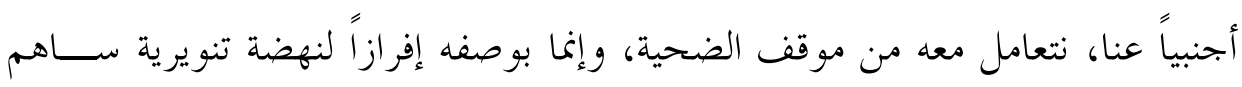

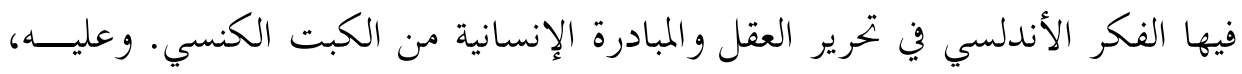

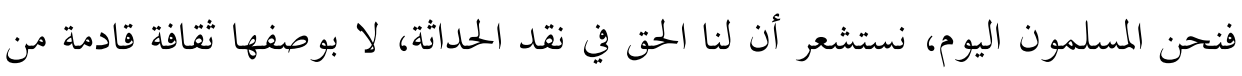

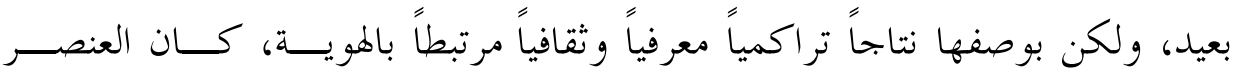

$$
\text { الإسلامي قد شكَّل لبنة من لبناته. }
$$


فمراجعتنا للحداثة الغربية ليست مراجعة الشرقي للغرب، و لا الروحي للمـــادة،

و إنما هي مر اجعة ذاتية داخلية لثقافة إنسانية مشتر كة. ومن حقنا ونحن جــزء منـــها؛ إيجابي في الماضي، وسبي في الحاضر (مستلهم لمنتجات الحداثة)، أن نعيد مراجعتـــها، ليس بوصفنا أغراباً، بل بوصفنا منتجين و ونتاجاً للحداثة، فإذاذا كانت كتابات ابنات ابن رشد

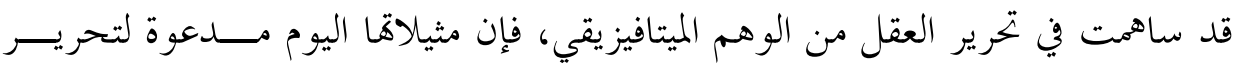
الإنسان من الوهم العقلاني العلموي في جوهره التكنولوجي، الذي أدى إلى انسدادات

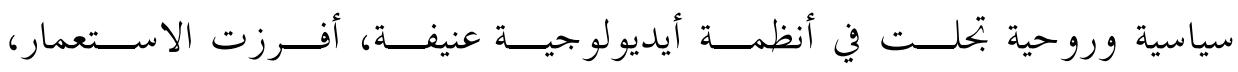
و الهولو كوست، و القو لاق.

فالحوار داخلي، ولنا الحق في أن نساهم فيه بوصفنا شركاء في بعسـث حضــاري

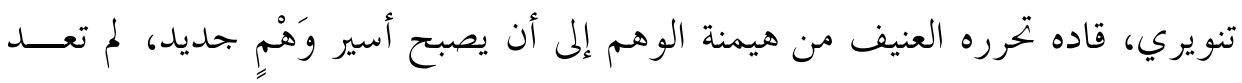

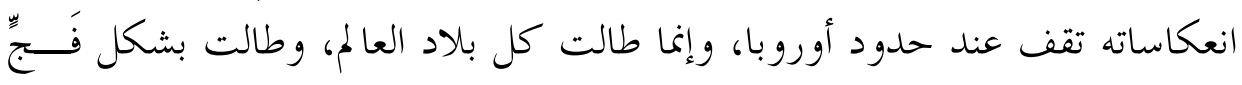
وغليظ بلدان العالم الإسلامي التي تعيش حالة من التشوه.

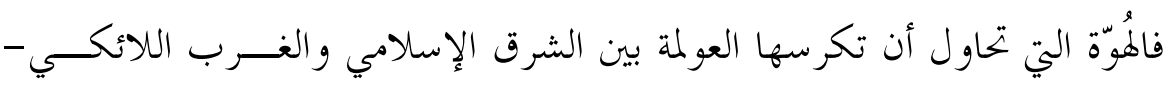
المسيحي -اليهودي، إنما هي هوة مفتعلة تعتمد خلق صورة نمطية للآخر الذي يجـــبـ تدميره؛ لتنبعث من رماده صورة الأنا. لذا يجب أن لا تنطلي علينا هذه الخدعة الــي ترمي إلى حلق حواجز وفواصل تعزز انطواءنا حول الذات، وتتول دون تواصلنا مــع الغرب الذي نختزله في صورة العدو اللدود، بينما الغرب أغراب. و يكفي أن نعزم على

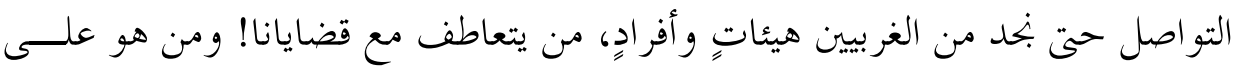
استعداد لإقامة جسور حوار وتعارف، بل وإقامة جبهة إنسانية لمقاومة الانعكاســات السلبية للعولمة على كافة الأصعدة. وإن هذه المقاومة قد تبدو في عرف بعض المــثقفين

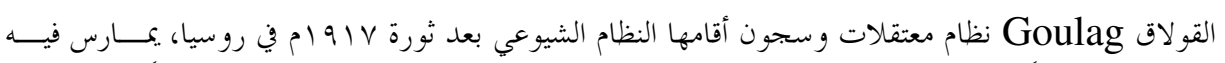

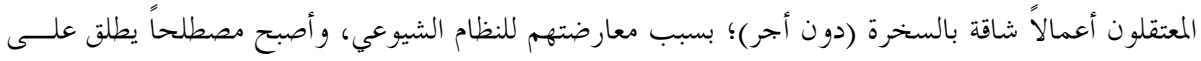
أي نظام همارس هذه القسوة على المعارضين السياسيين له. 
ضرباً من أحلام اليقظة، مفترضين أن العولمة قدر البشرية الجلديد الذي لا مناص مــن الاستسلام له، مرددين مع بعض الأصوات الغربية أغنية ذاية التاريخ والإنسان. إنَّ الأمر يتطلب مِنّا وقفة مع من يؤمنون بالحتمية الحضارية، ومن أعراضها عبثية الحوار بين طرفين لم يعترف أحدهما بتعادلية الحوار. ووفي الاعتراف إشكالية تســتدعي

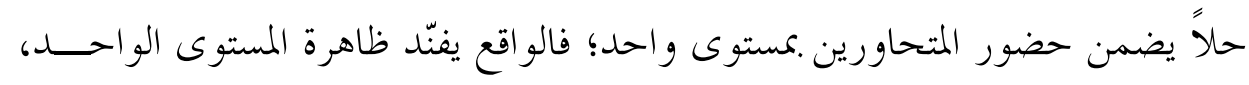
ويؤكد وجود مستويين بشرخ كبير بخمله في المعادلة الآتية: "المستوى الأول-المحــاور رقم - أي الغرب: قوي، يملك المرجع وآليات الحوار، كما يملك موضوع الحــــوار، المستوى الثاني-المحاور رقمب - أي الشرق: ضعيف، لا يملك المرجع، و لا يعي موضوع

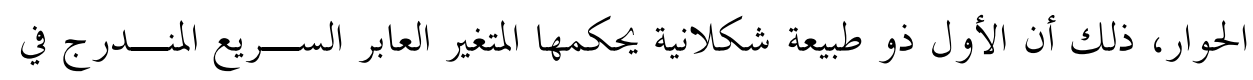
المصلحة، وهو المتغير المؤسس للسلامة المنهجية والفكرية عندها، أما الثاني فهو حاضر بطبيعة وجدانية قلقة، تتجاذبا صيغ الماضي والحاضر بضعف منهجي وبغموض معرفي،

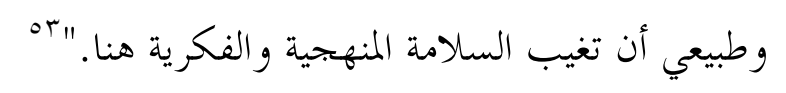

وللخرو ج من هشاشة الثاني وضعفه، يقترح بحموعة من المثقفين، الذين هم أسرى

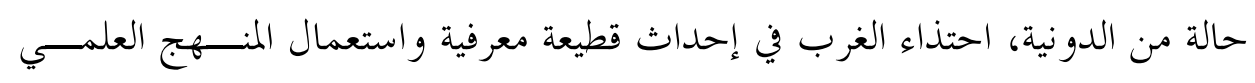

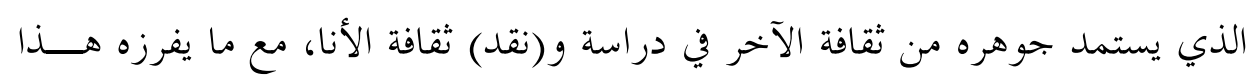
المنهج من رَفٍِ لكل قدسيةٍ للخطاب الغييي، وعدّه نصاً، بغض النظر عــن مصــــره

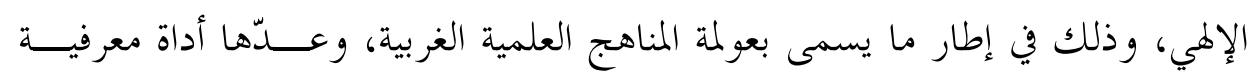
صالحة لكل زمان ومكان، و لا يأتيها الباطل من بين يديها ولا من خلفها. إن حملتنا على هذه النظرة لا تمس المناهج العلمية بوصفها و سائط معرفية؛ لأننا في

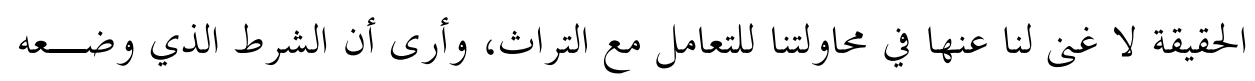

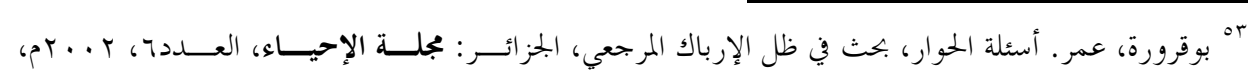




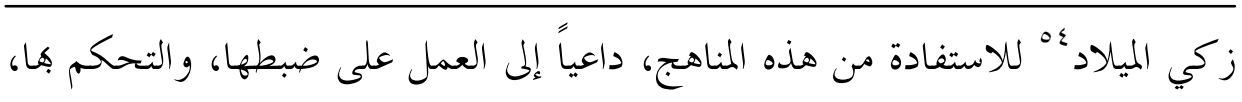

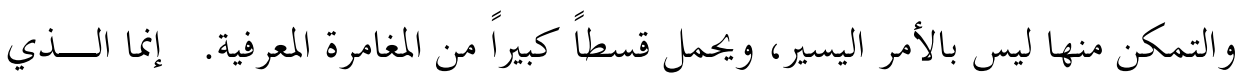

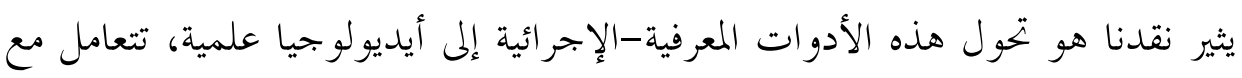

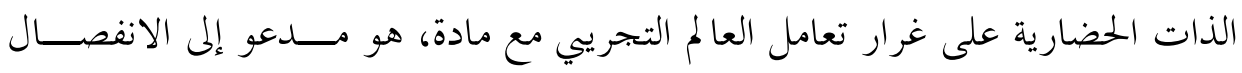
عنها؛ إذ هذا شرط موضوعي للوصول إلى النتائج العلمية المرجوة.

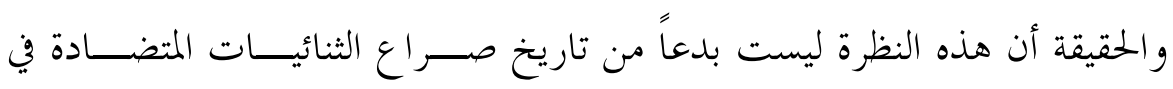

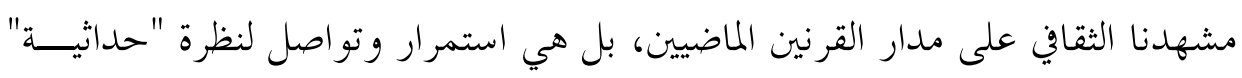

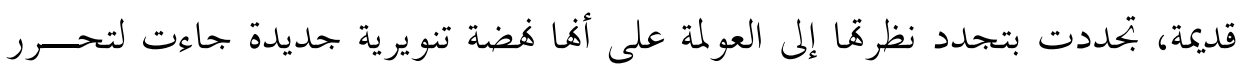

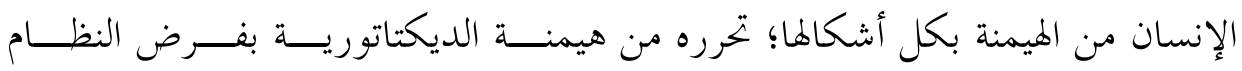

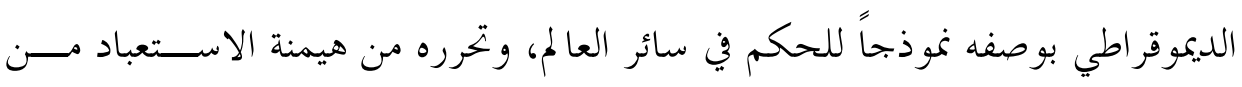

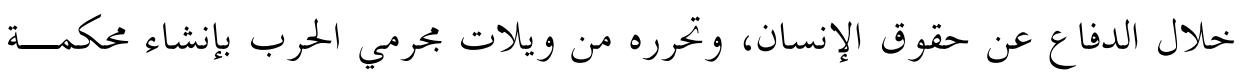

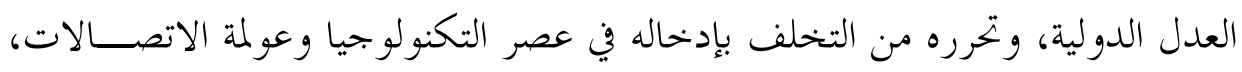

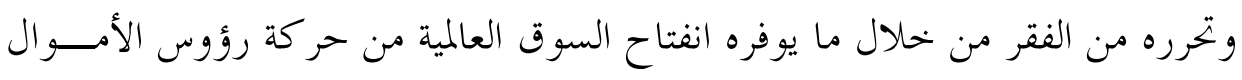

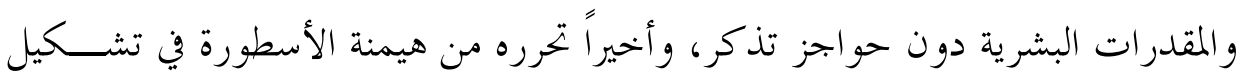

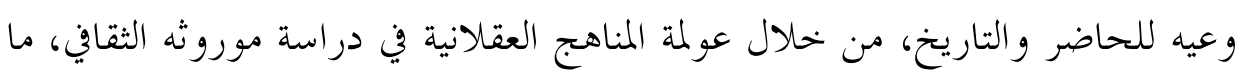
يؤهله للدخول في حوار مع الغرب من منطلق التكافؤ الحضاري.

ونحن بصدد مواجهة تحديات قرن جديد، بند أنّه ما زال كل فريق ينظر إلى العالم

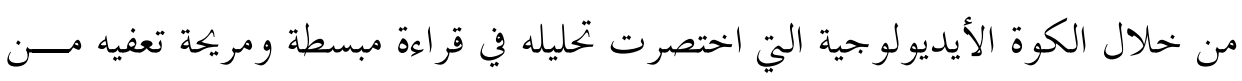

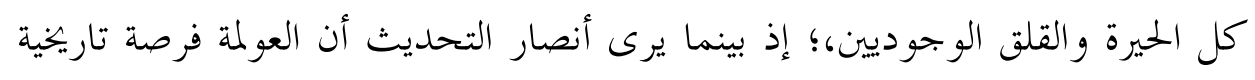

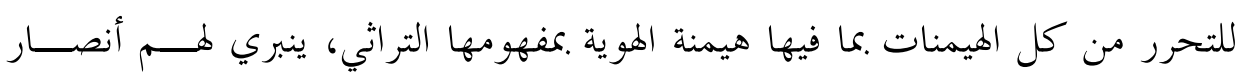

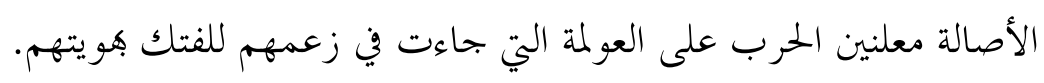

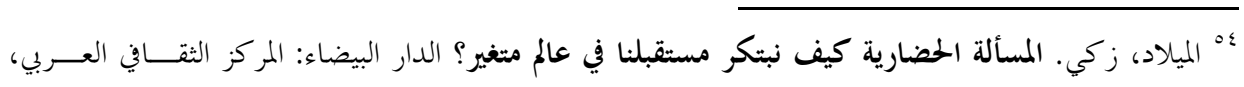




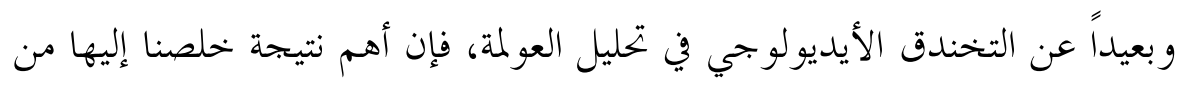

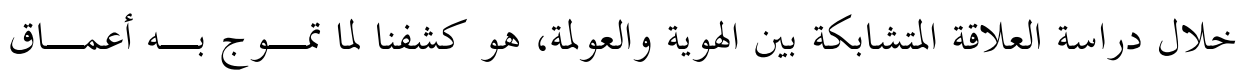

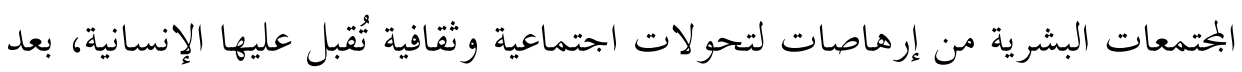

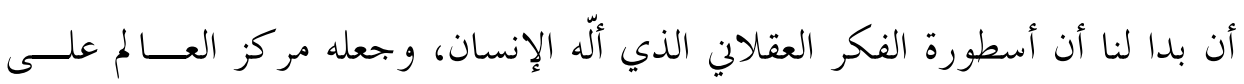

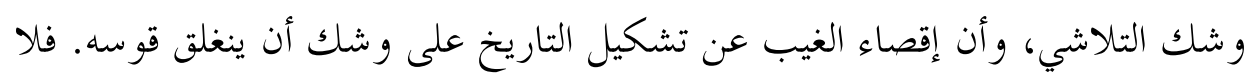

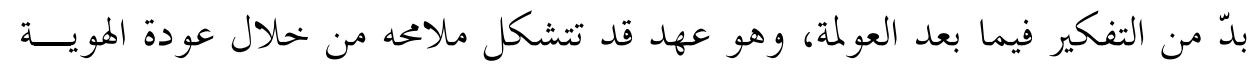

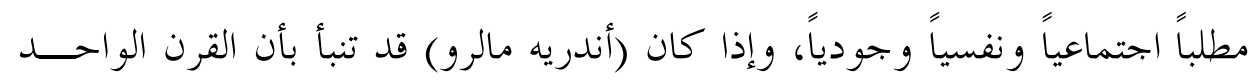

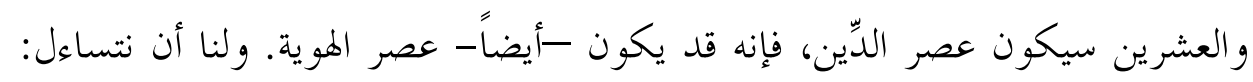

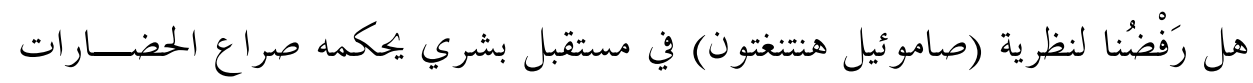

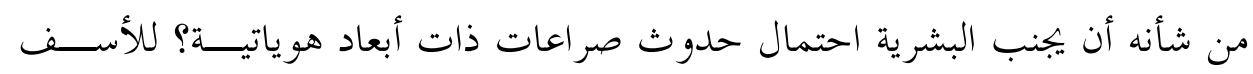

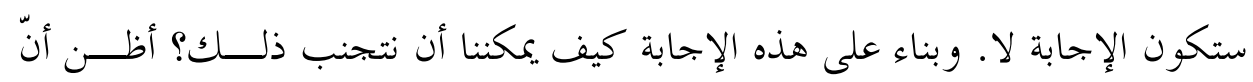

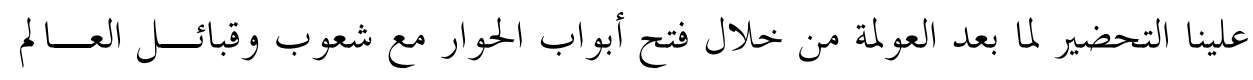

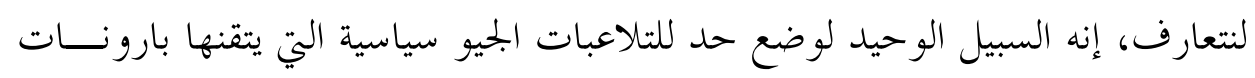
العولمة.

خاتمة:

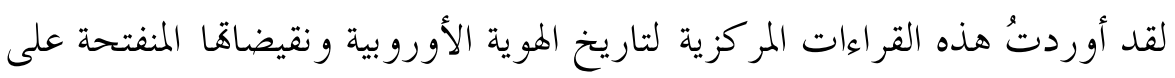

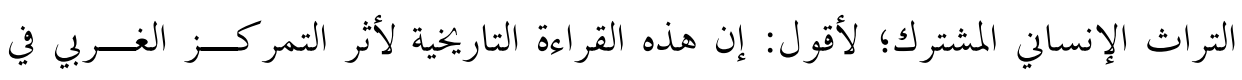

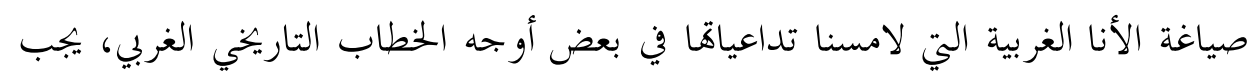

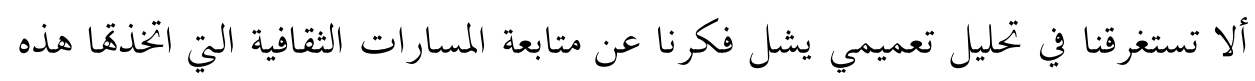
النظرة بفعل هزات تاريخية ألجأها إلى مر اجعة مسلماهما.

ولتحقيق ذلك علينا أن نتجاوز من جهتنا بعض المعوقات الذاتية، وهي ممثلة في: 
- الشرط الوهمي في ضرورة استيفاء الشروط اللازمة للوعي (وعي الذات، ووعي

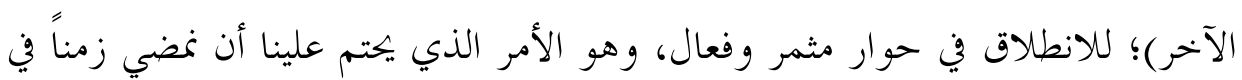

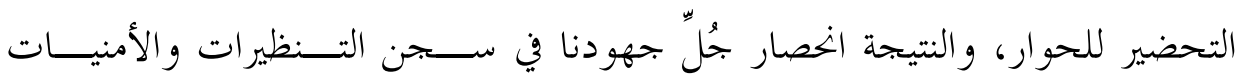
السعيدة، بينما يظل العالم من حولنا يضج بالحر كة و التحول. و كلما تو همنا استكمال

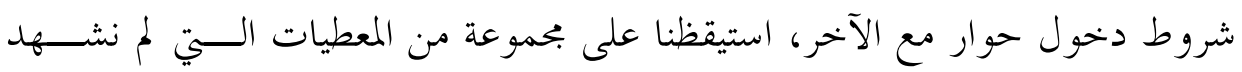

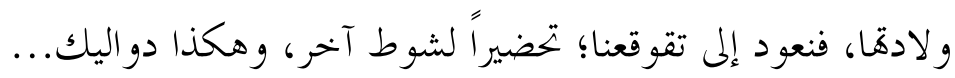

- ضرورة بناح الحوار الداخلي (الإسلامي- القومي- الوطني- اليساري)؛ إذ هو

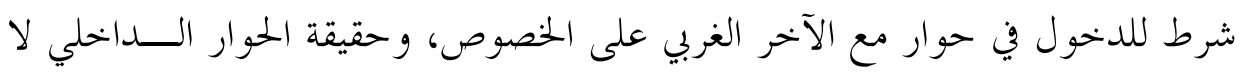

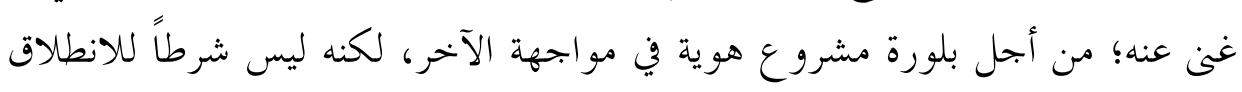

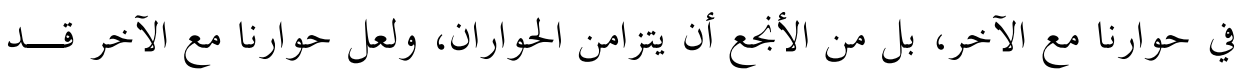

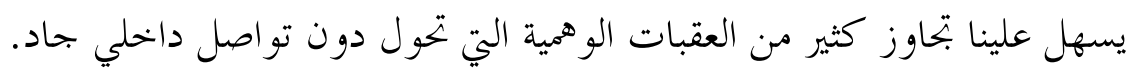

- نظرة التمركز الحضاري التي نعيبها على الغرب، ليست سمة دائمسـة للثقافـــة

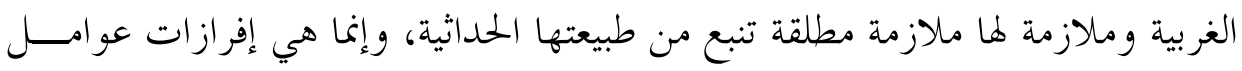

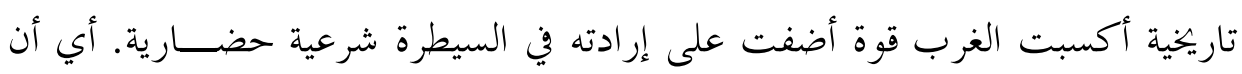

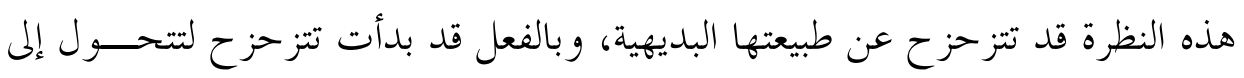

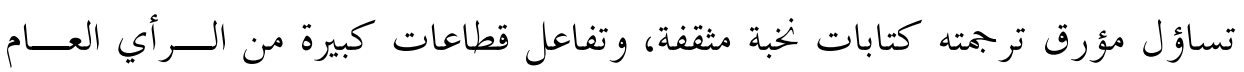

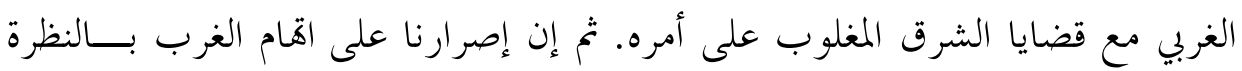

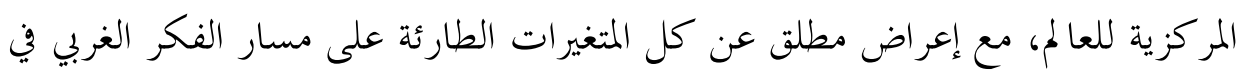

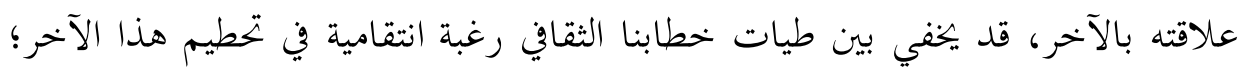

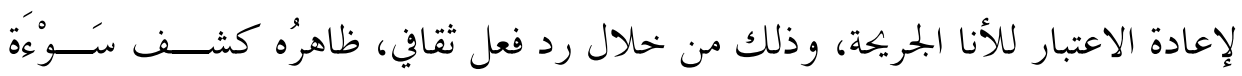

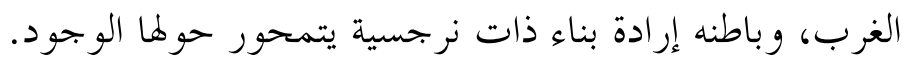

- نبذ رؤية الغرب بوصفه وحدة حضارية منسجمة بتمعها أيديولوجيا واحسـدة

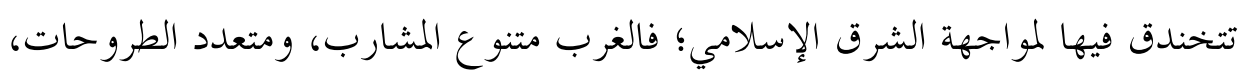


ومنفتح على التجارب الإنسانية الأخرى؛ لذا علينا أن نبحث عمّن يفهمنا ومن هــــ على استعداد لسماعنا، على أن تكون لدينا القابلية نفسها لسماع الآخر. ومن أجل ذلك فإننا جميعاً مدعوون إلى أن نرتقي بالمواجهة إلى مصاف الحـــوار حيث نبحث كلنا عن لقاء ثان بين الإنسان والعالم، وذلك من خلال تحقيــق غائيـــة

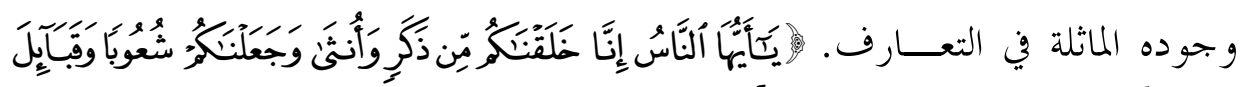

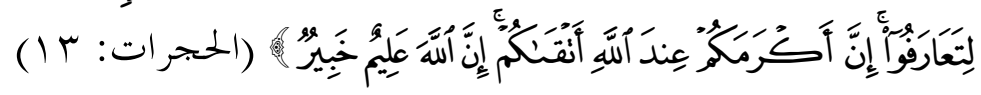

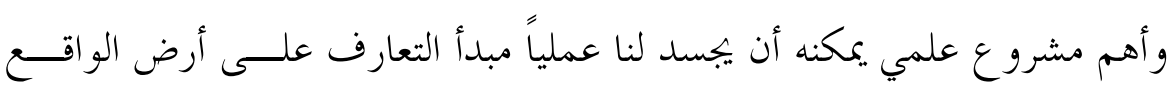
الثقافي، هو محاولة الوقوف عند طبيعة الصورة التي تخنزها ذاكرة كل هوية في تصورها

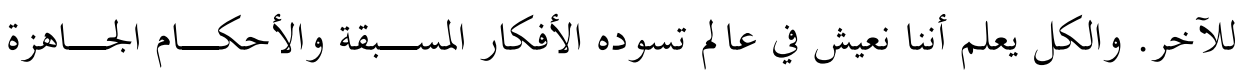

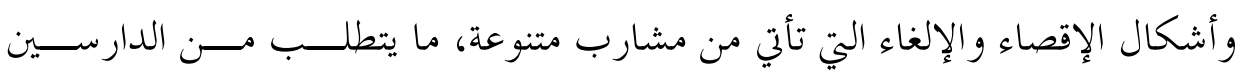
تأسيس معرفة بالثقافات و الشعوب قائمة على التبادل و التفاهم.

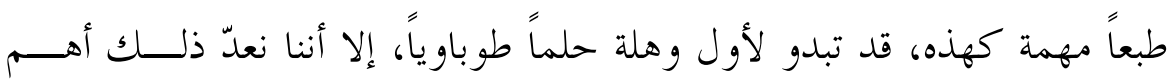
مسؤولية قد تُلقى على عاتق الدارس الجامعي في ميدان العلوم الإنسانية. وعليه فإنه لا بدَّ من إعادة التفكير في المناهل الأيديولوجية والأسطورية التي تستند عليها الثقافات في تبرير سياسة الانطو اء على الذات، ويغلب عليها شعور غامر بعقدة التفوق، أو في تمرير

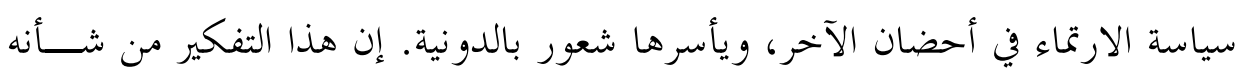
أن يساعد هؤلاء وهؤلاء على بتحاوز هذه العقد؛ من أجل إرساء ثقافة الاختلاف الذي

$$
\text { لا يفسد للود قضية. }
$$

